\title{
MESTIZOS Y MESTIZAJE EN LA COLONIA
}

Víctor M. Alvarez M. Universidad de Antioquia

Este trabajo fue presentado

\section{INTRODUCCIÓN}

Con motivo de la inauguración del CIHC, celebrada el 24 de

abril de 1997.

Sea, en primer lugar, mi agradecimiento por la gentil invitación a este foro al Profesor Hermes Tovar Pinzón y a los directivos del Instituto Colombiano de Cultura Hispánica, quienes en buena hora han tomado la feliz iniciativa de dar cuerpo al Centro de Investigaciones de Historia Colonial. He pensado que una sociedad como la nuestra, agitada permanentemente por la turbulencia de los hechos cotidianos, requiere del espacio institucional para la reflexión tranquila sobre el pasado y para el examen detenido de los procesos formadores que son, al fin de cuentas los que le dan identidad. Como simple estudioso de la vida colonial, intentaré algunas consideraciones que, estoy seguro, han estado presentes en la reflexión de ustedes para ciar cuerpo al Instituto que hoy nace. No obstante me animo a formularlas para contribuir a la evaluación de la importancia que tendría un Centro de la naturaleza del que inauguramos y para proponer mi modesto aporte a la construcción de la agenda que puede guiarlo.

Aunque parezca lugar común es menester volver a señalar que la disciplina histórica tiene un campo propio que la diferencia de las otras disciplinas llamadas «Sociales y humanas», aunque puede y debe encontrarse con ellas en la ardua tarea de comprender el devenir humano. Ese cam- 
po es el asunto de la temporalidad y, específicamente el de las relaciones entre Permanencia y Cambio. No cabe duda que una sociedad en crisis como la nuestra hace $\mathrm{y}$, está bien que así sea, énfasis en los procesos de cambio que la agitan todos los días. No obstante, es imperativo llamar a la reflexión sobre las permanencias y sobre los aspectos de «larga duración». Es bueno pensar que cuando los hombres individualmente considerados atraviesan procesos de crisis, vuelven sus ojos al pasado remoto de sus vidas, para indagar allí por su infancia, su juventud, sus experiencias familiares. El supuesto es que un ejercicio de tal naturaleza permite a cada quién saber de mejor manera quién es, qué lo identifica y cómo se ha construido su vida.

Sé los riesgos de una analogía como la que quiero proponer entre individuo y sociedad. Sin embargo, todo indica que también las sociedades requieren de ese esfuerzo para reconocer en su Historia las claves hacia el reconocimiento de lo que son. Son las permanencias las que dan a los pueblos identidad y sentido de pertenencia. Nadie duda que un individuo que ignora su infancia y su juventud es un enfermo y que un amnésico es alguien que, para poder convivir con los otros, requiere de todos los recursos y tratamientos a fin de que pueda recuperar su memoria. Algo similar puede pensarse de la memoria colectiva de una sociedad. Es preciso contribuir a que una sociedad que olvida lo que es, como la nuestra, vuelva los ojos al examen cuidadoso de su más remoto pasado. No para hacer un inventario selectivo de «lo malo, lo bueno y lo feo» sino para identificar la senda recorrida y reconocer así su propia identidad.

Hechas estas consideraciones muy generales, quiero llamar la atención sobre un problema particular, que, en mi modesta opinión, se halla apenas enunciado en lo relativo a la historia colonial y que, por su importancia requiere de la atención de los historiadores e implica el diseño de un gran programa de investigación. Me refiero a aquello que Jaime Jaramillo Uribe llamó hace más de 30 años: «Mestizaje y diferenciación social». Las páginas que siguen son el intento de proponer algunos perfiles del asunto.

\section{LAS DIVERSAS VISIONES DE LA CONQUISTA Y DE LA ÉPOCA COLONIAL}

Sobre el significado de la invasión y conquista de América y sobre las condiciones de la vida colonial ha existido una polémica que pareciera no concluir y que se reanima en determinadas coyunturas históricas como la reciente conmemoración del «Quinto Centenario» o en esta misma ocasión. En esa discusión se suele incluir la más amplia diversidad de temas y asuntos y cuentan desde las visiones que cada uno tiene de la sociedad, la política, la ética y la historia hasta las creencias religiosas, las nacionalidades y la pertenencia o afinidad con grupos étnicos y culturales. Sin duda, desde la misma época de la conquista europea se desata- 
ron importantes discusiones sobre la justificación y significado que esta empresa tenía. Recuérdese que, en aquel momento, algunos europeos cuestionaron duramente la acción de sus coterráneos en tierras americanas y la legitimidad de su conducta. El caso más conocido entre nosotros es el de un sacerdote, Fray Bartolomé de Las Casas, quien desde 1514 renunció a su encomienda en Cuba y después de regresar a España en 1540, hasta el fin de sus días, sostuvo una polémica pública combatiendo los saqueos, despojos, maltratos y destrucción que hacían los conquistadores entre los pueblos de América.

A comienzos del siglo XIX, con motivo de las luchas por la Independencia de los pueblos americanos y transcurridos tres siglos de dominación europea, la polémica sobre la validez y justificación de la conquista y sobre lo que significaba el legado colonial volvió a revivirse. Para muchos políticos e historiadores, la Independencia era una forma de resolver las «injusticias» que había traído consigo el régimen colonial después de la invasión europea. Para otros, los pueblos americanos habían llegado a la mayoría de edad y por lo mismo, la independencia era un acto de autonomía pero España seguía siendo la «Madre Patria». Así nacieron dos visiones opuestas de la conquista española y que se conocen hasta nuestro tiempo como la «leyenda negra» y la «leyenda rosa». Estas dos visiones, más que explicar el proceso cumplido con la dominación española, pretenden establecer un juicio de responsabilidades por lo ocurrido para saber si los europeos fueron «buenos o malos».

Según la «leyenda negra», los españoles -«hombres malos»- llevados por la codicia robaron los tesoros indígenas, torturaron, violaron y mataron a los aborígenes, destruyeron los pueblos y las culturas y sólo dejaron a su paso destrucción y violencia al servicio de sus propios intereses. Por el contrario, de acuerdo con la «leyenda rosa», los españoles -«hombres buenos»- trajeron a América la religión verdadera y con ella la salvación de las almas, la lengua castellana, la rueda, el ganado, las herramientas metálicas y, en general, la «civilización europea» que habría de ayudar a estos pueblos para superar la condición de «bárbaros y salvajes» que tenían en el momento de la conquista.

Hasta hoy estas dos visiones opuestas siguen inspirando las reflexiones de algunos estudiosos. En las nuevas condiciones de nuestra sociedad, la polémica sobre el asunto ha vuelto a plantearse y sigue predominando la tendencia al juicio sin una más profunda investigación de cómo se formaron estas sociedades y de las consecuencias de aquel proceso que siguen vigentes entre nosotros. De otra parte, más allá de la discusión ética o política del asunto, es comprensible que sean necesariamente diferentes las miradas que sobre estos acontecimientos y etapas pudieron tener los diversos grupos y pueblos comprometidos en aquella historia: europeos, indígenas americanos, negros de origen africano y mestizos. 


\section{AMÉRICA PARA LOS EUROPEOS}

Para los europeos, América es algo que ellos «descubrieron», conquistaron, dominaron y civilizaron. Pero, no sólo América. Los avances técnicos en la marinería hicieron posible múltiples exploraciones por los mares de la tierra. Viajes como el de Vasco de Gama circundando el África por el Cabo de la Buena Esperanza (1497) y el de Fernando de Magallanes navegando el mundo de oriente a occidente por el extremo sur de América (1519) contribuyeron al «Descubrimiento del Mar». Se ganó la idea de comunicación entre el Atlántico, el Pacífico y los otros mares o lo que es igual, se sabía ahora que había un sólo gran mar sobre la tierra. También los europeos encontraron en América la vida económica y las condiciones sociales que no tenían en sus naciones. En los primeros treinta años, desde 1492 hasta aproximadamente 1520 su interés se centró principalmente en recorrer las costas para realizar lo que llamaron «rescates». Por ello se entendía apropiarse de los tesoros indígenas, esclavizar a los americanos y aprovechar su fuerza de trabajo para obtener el oro y otros recursos. Durante esos 30 años emigraron hacia América cerca de 40.000 españoles.

En esa primera época se trataba de conseguir el mayor beneficio en el más corto tiempo. Con ese fin se recorrieron todas las costas del continente y se fundaron ciudades. En tierras colombianas, por ejemplo, Alonso de Ojeda fundó en 1509, San Sebastián de Urabá y, en 1510, Martín Fernández de Enciso, Santa María la Antigua del Darién, pero no era el propósito de los europeos establecerse en estas tierras. Varios de los primeros conquistadores, especialmente los capitanes, volvieron a Europa a disfrutar de las riquezas que habían conseguido como producto de sus empresas. Otros murieron en estas actividades guerreras y muchos otros -la mayoría- siguieron recorriendo las diversas regiones, participando en diferentes empresas de conquista y reinvirtiendo en ellas las ganancias obtenidas. Siempre era posible algo más!!!

Varios hechos cambiarían el panorama. El descubrimiento del Mar del Sur, como se llamó entonces al Océano Pacífico, hecho por la empresa de Balboa en 1513, dos años después el descubrimiento del Río de la Plata por Bartolomé Solís y el reconocimiento de la costa del Pacífico hecho por Pascual de Andagoya hacia 1522 mostraron cada vez mayores tierras para conquistar. Posteriormente la penetración al continente con las conquistas de México (1517-1521), Guatemala (1524), Santa Marta (1525) y Cartagena (1532) y la búsqueda del Perú, pusieron de manifiesto la inmensa riqueza de tierras, hombres y recursos que tenía el nuevo continente. Ante esta situación, la perspectiva de los europeos cambió. Ahora se trataba de establecerse en estas latitudes y proceder a la formación de un imperio colonial para España. 
Gracias al dominio sobre estas tierras, el mundo americano se convirtió en un espacio privilegiado para el crecimiento económico de naciones como España, Portugal e Inglaterra. Los colonos establecidos aquí se convirtieron en el más importante mercado para el comercio europeo. En menos de medio siglo se habían establecido en las nuevas colonias más de 200.000 emigrantes peninsulares que compraban bienes importados. Se contribuía así a resolver la crisis de marginalidad y desempleo que habían tenido en la península. Aunque los emigrantes encontraron en América, entre otros, recursos tan valiosos como maíz, yuca, cacao, papa, maní y frutales para su alimentación, guadua y fique para construcciones y tejidos, una gran diversidad de plantas medicinales y las favorables condiciones climáticas del trópico, la empresa militar de conquista y su propia cultura los mantenían ligados a Europa de donde se debían importar muchos bienes. Esta actitud, con algunas variaciones permaneció durante la época colonial. Ropas, herramientas, bebidas y muchos otros efectos fueron parte del arsenal de productos que circulaba por el Atlántico con destino al mercado americano y que se pagaba por los vecinos de América con el oro y la plata obtenidos en las tierras colonizadas.

Se comprende entonces el afán por despojar a los indígenas de oro, plata, perlas, esmeraldas y de todo cuanto hiciera posible la adquisición de esclavos africanos, animales, armas, muebles, joyas, objetos de arte, ropas y hasta medicinas y alimentos que eran traídos desde los puertos europeos. Pronto, los invasores pasarían a ser los propietarios de tierras y minas y a controlar el sistema productivo mediante el trabajo obligado de indios y negros. Sabemos poco del costo social y humano que tuvo este proceso para los europeos. Específicamente en el caso colombiano carecemos, por ejemplo, de una noción mínima de las muertes de europeos en este territorio. No obstante, a juzgar por ejemplos de algunas huestes, eran también abundantes las muertes de españoles, los graves conflictos de intereses y otros asuntos de no poca monta.

También las monarquías se consolidaron políticamente y aumentaron notoriamente su poder. Un ejemplo basta: como resultado de la conquista española la gloria mayor del Emperador Carlos V era que el sol no se ocultaba en sus dominios. Además, ese poder se veía fortalecido por virtud de la expansión creciente de la iglesia católica en las tierras controladas por España y Portugal. La conquista y la construcción de sociedades en las tierras colonizadas es también para ellos, el triunfo de la cristiandad y de la religión verdadera contra las creencias propias de los indios. Algo parecido habría de vivirse en otros países europeos como Francia, Inglaterra y Holanda con la conquista y colonización de Norteamérica y de las Antillas.

\section{LA CONQUISTA PARA LOS INDIOS AMERICANOS. GUERRA Y DESPOJO}

Si lo anterior significa gloria y orgullo para los europeos, estos mismos acontecimientos tienen otro significado para los indios americanos. La empresa de Colón y, después de 
ella todas las demás empresas de conquista y colonización representan para los pueblos indígenas, en primer lugar la invasión y la guerra. Guerra porque sus tierras son invadidas por ejércitos extranjeros y es preciso combatirlos para defender su existencia como pueblos. Aunque se trata de una respuesta general, la particularidad y duración de esa guerra fue muy diversa. En lo que hoy es el territorio colombiano fueron derrotados y sometidos en corto tiempo, entre otros, los Chibchas, Pastos, Quillacingas y Guanes. Para otros pueblos esa guerra se prolonga durante muchos años y aún siglos. Casi medio siglo necesitaron los europeos para lograr la destrucción y derrota de los pueblos costaneros denominados genéricamente como caribes y un tiempo similar para desarticular la resistencia y hostilidad de Catíos, Nutabes, Tahamíes, Armas y Caramantas en la región antioqueña. La resistencia de los Sindaguas, Pijaos, Paeces y Guambíanos en el suroccidente colombiano, de los Carare-Opón en el curso medio del río Magdalena, de Chimilas, Tunebos y Motilones, Guajiros y Cunas de Urabá son ejemplos vivos de una guerra que ha durado siglos. Hasta nuestro tiempo, la mayoría de ellos sigue oponiéndose beligerantemente a la presencia del colonizador europeo.

Pero la guerra entre invasores e indígenas era apenas el recurso para obtener el control de bienes y hombres. Para los indios la consecuencia inmediata de su derrota militar era el saqueo y destrucción de sus sepulcros y de sus templos en donde conservaban adornos y objetos de oro, plata y esmeraldas con fines rituales y decorativos. En corto tiempo, también la conquista significó para los naturales la obligación de entregar sus productos y su trabajo como tributo a los encomenderos. Oro, mantas, vasijas, alimentos y muchos otros objetos que antes se producían para la comunidad, ahora debían entregarse al español quien los aprovechaba junto con el trabajo indígena para la explotación de las minas y para el trabajo de la tierra que también se quitaba a los aborígenes. Más que las propias guerras de conquista esta forma de dominación habría de afectar duramente las condiciones de vida de los pueblos sometidos. Si a ello se agrega la destrucción de la organización familiar combatida pollos europeos por considerarla pecaminosa y el cambio de condiciones sociales, puede entenderse la grave crisis que esto representó para los indígenas.

Fueron numerosas las muertes causadas por la guerra de conquista. No obstante es después, a partir del establecimiento de ciudades y encomiendas, como ejes de la dominación colonial, cuando se produce la mayor despoblación de los indios. Tres ejemplos ilustran este proceso: entre 1550 y 1602 la población de la provincia de Tunja pasó de 200.000 habitantes a apenas la cuarta parte, 50.000 pobladores. La zona de los Quimbayas o provincia de Cartago tenía en 1559 un total de 18.000 indígenas y, medio siglo después, en 1605, apenas quedaban 140 tributarios. Tal vez el caso más dramático sea el de Antioquia en donde un visitador, Fray Jerónimo de Escobar, revelaba en 1582 que, de más de 100.000 habitantes en el momento de la conquista, sólo quedaban 800 indios y 600 esclavos africanos pues, según sus palabras, 
«...así por los grandes pecados de estos indios y abominaciones debió de permitir Dios se asolasen estos y otros muchos porque a la verdad la gran ruina y acabamiento de esta provincia de Antiochia no debe de haber sido la causa de sus muertes la sujeción que los españoles les han puesto, pues era mucho mayor y de mayores trabajos la que ellos tenían a sus caciques y gobernadores...». ${ }^{1}$

También la conquista significó para los aborígenes americanos el conocimiento de nuevos elementos productivos que debían cultivar, utilizar y cuidar para sus encomenderos y, posteriormente, para los descendientes de éstos que fueron los propietarios criollos. Los españoles trajeron alimentos como el trigo, la cebada y la caña de azúcar; animales útiles como caballos, ganado vacuno, ovejas, cerdos y cabras que sirvieron para ocupar rápidamente grandes extensiones de tierra; herramientas metálicas y arados que sustituyeron los instrumentas de madera y hueso utilizados por los aborígenes y nuevas técnicas de trabajo agrícola, minero y artesanal. Una nueva lengua de uso general -el castellano- también fue conocida por los indígenas. Obligados a utilizar este nuevo idioma, poco a poco los indios experimentaron la desaparición de sus lenguas tradicionales.

Finalmente, los indios americanos conocieron así mismo una nueva religión, la católica. Unas veces por la convicción y muchas otras por la imposición, esta forma de pensamiento religioso sustituyó la multiplicidad de mitos y creencias que les eran propias desde tiempos inmemoriales. En síntesis, la derrota militar de la conquista significó para los aborígenes la pérdida de sus bienes, de su organización social, de su cultura y hasta de su propia vida. ¿Cómo no entender que la rechazaran enfáticamente? La etapa subsiguiente de funcionamiento institucional de la encomienda, de reducción drástica de la población, de reducción a pueblos y resguardos puso toda su energía laboral al servicio de la consolidación de los Criollos -blancos americanoscomo detentadores del poder y como grandes beneficiarios de su labor.

\section{LA COLONIA Y LA ESCLAVITUD PARA LOS AFRICANOS}

Para los africanos esta es una historia de esclavización de varios millones de hombres, de despojo de sus recursos minerales y vegetales y de destrucción de muchas de sus tradiciones políticas y culturales. Se calcula que sólo a la Nueva Granada llegaron más de 200.000 esclavos africanos. Esa es una cifra muy pequeña en comparación con las inmensas cantidades de hombres que después de su captura y esclavización eran conducidos por ingleses, portugueses, franceses y españoles a otras regiones americanas como Venezuela, Norteamérica, el Caribe y Brasil en donde hasta hoy permanecen como componente básico de su población.

1 Fray Jerónimo de Escobar, «Relación de Popayán. 1582», Cespedesia, Cali, No. 45-46, Pág. 302. 
Extraídos y separados de sus respectivos pueblos y rotas las formas de su vida tradicional los esclavos africanos fueron también desarticulados culturalmente. Se les obligó a cambiar su lengua, su religión, sus formas de pensamiento y aún su vida cotidiana. Desde el punto de vista económico, debieron reemplazar a los indios en las duras tareas de la minería, la carga en los puertos, la boga de los ríos, los cultivos y el cuidado de ganados en las zonas más cálidas del territorio. En cada una de las regiones de la Nueva Granada y especialmente en Antioquia y el Cauca la historia de la extracción y beneficio del oro es así mismo una historia de la esclavitud que le servía de soporte. La historia de la trata de esclavos y la del poblamiento y el comercio en la costa Atlántica lo es también de una sociedad de profundos perfiles esclavistas. También el trabajo negro sería sustancial para la economía agraria en América. Gracias a él se hizo posible el surgimiento de las grandes plantaciones de caña y tabaco que, desde la época colonial, abastecían el mercado mundial.

\section{UN INTENTO DE NUEVA BÚSQUEDA. ¿Y NOSOTROS LOS MESTIZOS?}

Como puede apreciarse, resulta comprensible que exista una gran diversidad de juicios y valoraciones acerca de lo que han significado los últimos 500 años de historia americana. Para los mestizos, que somos la mayoría de los latinoamericanos, es claro que nuestra situación, es el resultado de una fusión de elementos heredados de los tres grupos originales. Pero que nuestra condición es distinta, aunque sea resultado de la historia vivida desde entonces. El juicio general acerca de si fue bueno o malo lo ocurrido nos aporta poco. Parece preferible tratar de comprender y valorar adecuadamente la herencia recibida de nuestros antecesores y saber que tenemos una historia propia que nos vincula con aquellos procesos.

Definitivamente, no somos europeos ni nuestra aspiración es la de serlo. Aunque sobreviven muchos y muy importantes pueblos indígenas y núcleos de poblamiento afro-americano, la mayoría de los habitantes de hoy en Colombia y Latinoamérica somos otra cosa: mestizos. Y eso representa ser herederos de muchos elementos de origen europeo, americano y africano pero también partícipes y sujetos activos de una historia que es diferente, aunque complementaria de la de indios, negros o «cristianos». Es allí en donde adquiere su mayor significado el estudio de la época colonial que, a la manera de un crisol hizo posible la formación del mestizaje. En efecto, esos dos y medio siglos que separan la Conquista de la Independencia y que nuestra historiografía ignoró durante mucho tiempo produjeron un resultado que podría sintetizarse como la formación de sociedades mestizas y en ello, el caso de la Nueva Granada es especialmente notable. 


\section{MESTIZOS Y AMERICANOS}

Promediando el mismo siglo XVI, a pesar de la afluencia progresiva de europeos a estas tierras y de la notoria destrucción de los aborígenes, la composición étnica de la población americana mostraba una muy importante mayoría de indígenas, un número cada vez más grande de negros africanos y una franca minoría de españoles. Aunque esta era la tendencia general, en algunas regiones las proporciones eran diferentes. Por ejemplo, desde 1580, en la provincia de Antioquia la rapidísima desaparición de los indios dio paso a un número grande de esclavos africanos para abastecer de fuerza de trabajo a los ricos yacimientos mineros del río Cauca, de Cáceres, Remedios y Zaragoza y, comenzando el siglo XVII de Guamocó. Se ha calculado que hacia el año de 1600 quedaban en Antioquia unos centenares de indios, 300 vecinos españoles y más de 5000 esclavos negros. La población negra seguiría aumentando durante el siglo XVII pues además de la labor de minas, a los negros se les fueron otorgando tareas como la boga de los ríos, la ganadería, el cultivo de la caña de azúcar y el servicio doméstico en la costa, en el Cauca, en Antioquia y aún en Santander y Cundinamarca.

El resultado visible de esta situación es que, a lo largo del siglo XVII y más notoriamente durante el siglo XVIII, la desaparición de los indígenas y el intercambio creciente de relaciones entre los distintos grupos dieron lugar a la formación de una capa cada vez mayor de individuos que no podían considerarse como indios -no tributaban- ni como negros pues no eran esclavos.

\section{LOS PRIMEROS MESTIZOS. EL SIGLO XVI}

Desde el propio siglo XVI, antes de cumplirse el medio siglo de presencia europea en el Nuevo Reino de Granada, ya el caso de los mestizos y del mestizaje empezaba a preocupar a los europeos como un asunto propio y específico de América. Los relatos sobre empresas de conquista permiten conocer de qué manera los españoles encontraron, desde los primeros tiempos los favores sexuales de las mujeres indígenas. Uno de los primeros episodios en este sentido se presentó con motivo del amotinamiento de Francisco Roldan contra Diego Colón en Santo Domingo. Según los testimonios de Hernando Colón y de Las Casas, los amotinados se fueron a la provincia de Xaragua «donde las mujeres eran más hermosas y de agradable trato y esto era lo que más les animaba para irse allí». ${ }^{2}$

En 1503 fue ahorcada por sospechas de un alzamiento contra los españoles en la Isla Española la cacica Anacaona. De esta india que era hermana del cacique Behechio y mujer de Caonabo dice Oviedo que

2 Víctor Manuel Patino. Historia de la Cultura material en ja América equinoccial, Vol. VII, Vida erótica y costumbres higiénicas, Santafé de Bogotá, Instituto Caro y Cuervo, 1993, Pág. 36. 
«fué muy disoluta, y ella y las otras mujeres de esta isla aunque con los indios eran buenas y no tan claramente lujuriosas, fácilmente a los cristianos se concedían e no les negaban sus personas... pero muy deshonesta en el acto venéreo con los cristianos e por esto e otras cosas semejantes, quedó reputada y tenida por la más disoluta mujer que de su manera ni otra hubo en esta isla... ${ }^{3}$.

Bastidas dormía en Santa Marta acompañado por mujeres indígenas cuando fue objeto de un atentado por miembros de su propia hueste: «Como el gobernador y algunas indias de servicio que en su propio aposento dormían diesen voces y apellidasen el socorro de la gente del pueblo.... ${ }^{4}$ En la expedición de Francisco Montejo a Yucatán, hacia 1520, iba un español que tenía por costumbre embarazar a las indígenas que capturaba para obtener de ellas un mayor beneficio. Según Bartolomé de Las Casas: «Este hombre perdido se loó e jactó delante de un venerable religioso, desvergonzadamente, diciendo que trabajaba cuanto podía por empreñar muchas mujeres indias, para que viéndolas preñadas, por esclavas le diesen más precio de dinero por ellas» ${ }^{5}$.

En el Perú, después de la muerte de Atahualpa se capturaron más de cinco mil indias de servicio y concubinas muy hermosas y fueron repartidas entre los capitanes para su servicio. El propio Pizarro tomó por mancebas varias indias del linaje real incaico. Según un testigo de esta situación:

«En lo que toca a la deshonestidad, iba tan roto el negocio, que desde el capitán hasta el mismo soldado vivían miserablemente, cual con cinco, cual con diez, cual con doce mancebas y todas gentiles, y todas ellas quitadas o de sus padres que las tenían doncellas para casar, o de sus maridos; y por quitar escrapulillos, las hacían bautizar sin catecismo ni prevención alguna, y acabado el bautismo, las hacían volver a sus casas y pecados, y las que poco antes fueron mancebas gentiles, el mismo día del bautismo se hacían mancebas bautizadas y cristianas. Y quitaban también muchachos a sus padres para servirse de ellos de alcahuetes para hacer llamar hoy aquesta, mañana aquella...». ${ }^{6}$

Las mujeres de la provincia de los Cañares, súbditos del imperio inca, fueron descritas como «hermosas y no poco ardientes en lujuria, amigas de españoles». ${ }^{7}$

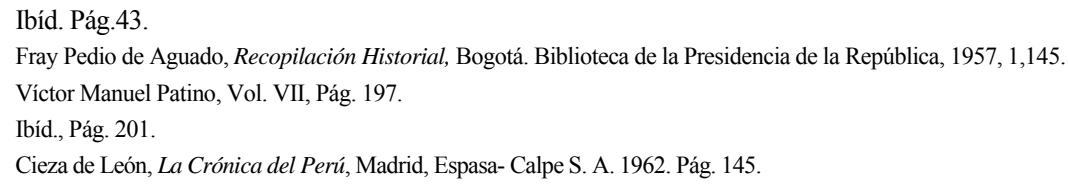


El lo de julio de 1540, entre los cargos formulados al Gobernador Rodrigo de Contreras se afirmaba que:

«...consiente que un pueblo de indios que tiene en administración que se dice Teotega, se alquilen las indias libres de él a marineros y a otras personas que están en el puerto del Realejo... esto para que se echen con tales personas e ansí por una india hermosa piden a un precio y por otra que no lo es tanto, otro precio, y si otra persona las alquila, le castigan y le echan pena por ello». ${ }^{8}$

Por su parte el padre José Anchieta, quien llegó al Brasil en 1552, al hablar de las mujeres de algunas tribus de ese territorio dice: «...las mujeres andan desnudas y no saben negarse a ninguno, sino que ellas mismas acometen e importunan a los hombres... porque tienen en mucha honra dormir con los cristianos...». ${ }^{9}$ Que era frecuente la incorporación de mujeres indígenas como compañeras de los conquistadores en las empresas de conquista lo deja apreciar Pedro Simón:

«Y esto de llevar indias en las jornadas es el pecado original en que todas las de estas tierras caen, no escapándose ninguna, porque a título de llevar servicio, entran los más a todos soldados amancebados con ellas, que yendo en estos pecados tan de asiento, mal pueden lucir sus aciertos y facciones pues no sé yo quién se atreverá a pedirle merced de buen suceso a Dios, teniéndole ofendido». ${ }^{10}$

Desde los inicios de la conquista se hizo frecuente que los propios caciques entregaran mujeres indígenas a los conquistadores. Así lo hizo en Urabá el cacique Careta, hacia 1511, al conceder su propia hija Anayansi a Vasco Núñez de Balboa. Según afirma un historiador, esta princesa indígena: «...vino a constituirse en intérprete de gran utilidad y por su fidelidad hubo de captarse el verdadero afecto de Balboa y prevenirlo de muchos peligros que le acechaban». ${ }^{11}$

Hacia 1532 otro gran cacique de Urabá dio su propia hermana por mujer al capitán Julián Gutiérrez. Este que se considera el primer matrimonio entre español e indígena reportó no pocos beneficios a Gutiérrez en sus correrías por las costas de Urabá. La india, bautizada como Isabel del Corral servía de intérprete, guía, embajadora y compañera del conquistador en cada uno de los seis viajes que éste realizó. Baste referir que en el primero de estos viajes Gutiérrez consiguió un botín de

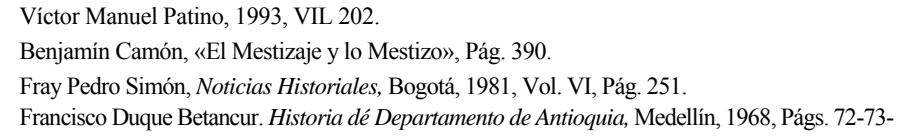


collares, cascabeles, pulseras y otros adornos avaluados en la inmensa cantidad de 678.000 pesos y que, aunque con menores botines, las demás expediciones de este conquistador fueron igualmente rentables. Su matrimonio había resultado una muy buena inversión. En 1535 el Obispo de Cartagena informaba a la Corona que los indios de Urabá querían mucho a Julián Gutiérrez «ansi por estar casado con una india natural de allí como también porque con amor y sin guerra y desasosiego había contratado...» ${ }^{12}$

Según Simón: «Lucióle este parentesco al Julián Gutiérrez con el Urabá pues desde su villa de Acla podían entrar él y su gente todas las veces que querían y por donde les era de más importancia, sin alguna resistencia, a hacer rescates que eran los mejores y más ricos de todas aquellas costas» ${ }^{13}$

Sin duda, fue muy grande el número de indígenas que se incorporó al servicio de las huestes y, entre ellos, muy importante la presencia femenina. En otras oportunidades de buen grado las mujeres indígenas, según relata el cronista, «se enamoraban de los invasores» como la hermana del cacique de los Catíos Agrazava quien además de delatar la conspiración que fraguaban los de su propio pueblo se entregó al capitán Antonio Osorio de Paz y fue bautizada como «Catalina».

Esta historia que se repite en muchos lugares del continente ha tenido como ejemplo más sobresaliente el de la «Malinche», mujer noble azteca con cuya colaboración pudo Hernán Cortés conquistar a México y quien fue bautizada con el nombre español de «Doña Marina». La «Malinche" era una noble indígena que los caciques del pueblo de Tabasco (México) regalaron junto con otras 19 mujeres al conquistador Cortés. Como «Doña Marina» se convirtió al cristianismo y fue la intérprete de Cortés durante la conquista de los Aztecas. En más de una ocasión le comunicó a éste las emboscadas y movimientos de los indios, convirtiéndose en figura clave de ese proceso. Esta indígena tuvo un hijo con Cortés y posteriormente se casó el conquistador Juan Jaramillo. ${ }^{14}$

Por esta situación y por la notoria escasez de mujeres blancas durante la conquista son abundantes los ejemplos de hijos nacidos de aquel primer encuentro. Hernán Cortés, conquistador de México, además del hijo mestizo que tuvo con doña Marina, tuvo una hija en una india de Cuba y dos hijas con aborígenes mexicanas. Según el cronista Bernal Díaz, Cortés era «con demasía dado a mujeres e celoso de guardar las suyas». ${ }^{15}$ Belalcázar legitimó en 1540, cuando estuvo en la corte solicitando que le fuera otorgada una gobernación, tres hijos naturales, presumiblemente mestizos. En su testamento mencionó como

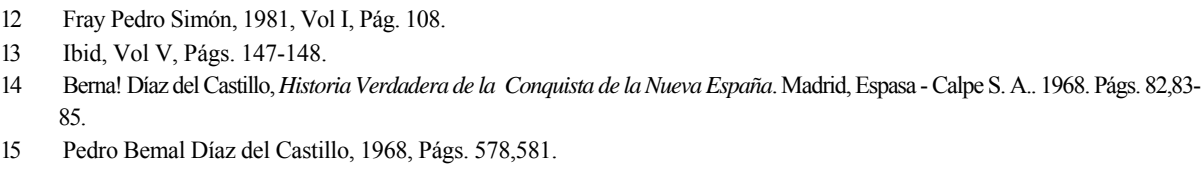


herederos a «don Francisco, don Sebastián, don Lázaro y doña Magdalena, y otros hijos e hijas». El primogénito, don Francisco, hijo de una indígena de Panamá o Nicaragua, fue teniente de gobernador en la ciudad de Popayán y disfrutó de una encomienda en esa región. La expedición que salió de Quito hacia el Nuevo Reino y que estaba capitaneada por Sebastián de Belalcázar traía consigo varios miles de «indios de servicio» entre los que se contaba un apreciable número de mujeres. Hacia 1541 con motivo del conflicto entre Lebrón y Hernán Pérez de Quesada se acusaba a éste de tener preferencia por Juan de Arévalo. Según se relata en el expediente Arévalo tenía una india Yunbo traída del Perú y se la prestaba ocasionalmente a Hernán Pérez quien: «se echaba con la dicha india a que por causa de ella trataba bien el dicho Juan de Arévalo, porque más prefería el rabo de la dicha india que la conversación de sus amigos.»). ${ }^{17}$

Con base en este mismo acontecimiento Juan de Castellanos mostró la práctica de algunos «peruleros» con este relato:

$$
\begin{aligned}
& \text { «...Y el pobre Fernán Pérez era vano } \\
& \text { No poco sensual y derramado } \\
& \text { Y aquellos del Perú porque les diese } \\
& \text { Lo más aventajado de la tierra } \\
& \text { Usaban de lisonjas y del cebo } \\
& \text { Que tenían los lenones de costumbre } \\
& \text { Cuando buscan con mozas su ganancia } \\
& \text { De que venían todos proveídos } \\
& \text { Pues había soldado que traía } \\
& \text { Ciento y cincuenta piezas de servicio } \\
& \text { Entre machos y hembras amorosas } \\
& \text { Las cuales regalaban a sus amos } \\
& \text { En cama y en otros ministerios } \\
& \text { Y de las mas lustrosas le enviaban } \\
& \text { so color de llevar algún mensaje } \\
& \text { o con alguna buena golosina... }
\end{aligned}
$$

Aunque más raro, también desde los primeros tiempos se encuentran algunos testimonios de relaciones entre mujeres blancas e indios. Cuando en 1573 marchó la empresa de Melchor de Salazar a la conquista del Chocó, por el Río San Juan encontraron que entre los indios de la zona se encontraban, «... dos españolas que habían traído de la agua grande salada, que es decir del mar, donde las asieron... y que ahora las tenían dos caciques en su servicio de quien tenían cinco hijos...». ${ }^{19}$

16 James Lockhart, Los Hombres de Cajamarca. Vol. I. Págs. 139-141.

17 José Ignacio Avellaneda Navas., La expedición de Sebastian de Belalcazar al Mar del Nortey su llegada al Nuevo Reino de Granda. Bogotá, Banco de la República. 1992, Pág. 29

18 Juan de Castellanos, Elegías de varones ilustres de Indias, Bogotá. Biblioteca de la Presidencia de Colombia, 1955. Vol. IV, Pág. 444. 
Lo cierto es que un buen número de los capitanes de conquista tuvieron hijos mestizos. Entre otros, son bien conocidos los casos de los cuatro hijos mestizos de Cortés, los de Pizarro y otros cuatro de Belalcázar. Muchos de estos hijos de conquistador participaron desde los primeros tiempos en la tarea de conquista. Por ejemplo, con Sebastián de Belalcázar fueron a la conquista de Santafé, entre otros, su propio hijo tenido con una «señora americana» de nombre Francisco; Lucas Bejarano, hijo de «Beatriz», una india mexicana traída al Nuevo Reino y Mencia de Collantes quien era hija de Juan Muñoz de Collantes y de una sobrina de Huayna Capac llamada Francisca Inga que había nacido en el Cuzco. Esta mestiza es la bisabuela del Obispo de Santa Marta y famoso cronista Lucas Fernández de Piedrahita. ${ }^{20} \mathrm{Y}$, como lo han mostrado recientes investigaciones, se halla en los ancestros de muchos de los «blancos» de Antioquia. ${ }^{21}$ Aunque no puede generalizarse, es posible afirmar que un buen número de mestizos, hijos de conquistador e india siguieron al lado de sus padres contribuyendo con ellos en la tarea de conquista. En 1541, cuando Belalcázar marchaba contra los paeces contaba en su ejército con la participación del mestizo Francisco Nieto. ${ }^{22}$ Años después, en 1569 cuando Quesada alistaba su empresa en búsqueda de El Dorado, dice el cronista que llevaba consigo hacia San Juan de los Llanos: «...más de 1500 indios de servicio, con «otras muchas mujeres españolas y mestizas, casadas y con sus maridos y otras aventureras... con mucha cantidad de negros y negras esclavas, más de $1000 \ldots$ y un mozo mestizo, hijo del capitán Antonio de Olalla». ${ }^{23}$

Un buen ejemplo de estos mestizos hijos de conquistador e india, desde temprana época se encuentra en Antioquia. Mencionemos unos casos para ilustrar el asunto: Un compañero de Robledo, Juan Taborda que llegó por el año de 1546 a Antioquia y fue encargado en 1567 de reedificar la ciudad declaró en su testamento de 1569 que dejaba varios hijos naturales a saber: Francisco Taborda, mestizo, nacido por 1551; Dieguito, mestizo y menor; Alonso y Bartolomico, mulatos, hijos de Lucía negra esclava y acepta como suyos a los hijos que nazcan de la india Ursulica y de la india Luisa, de su servicio, que dice estar preñada del capitán Taborda. De ellos, Francisco participó en las conquistas de Rodas; Diego fue a la conquista del Guazuze con Pedro Martin (también mestizo), en 1595 y allí murió. El mulato Alonso Taborda fue soldado de Rodas. ${ }^{24}$

El otro ejemplo es el caso de Gaspar de Rodas quien «nunca se casó pero dejó varios hijos»), uno de los cuales (Alonso de Rodas Carvajal hijo de la india Catalina) participó como capitán en las empresas de pacificación y población Cáceres (1575) y de

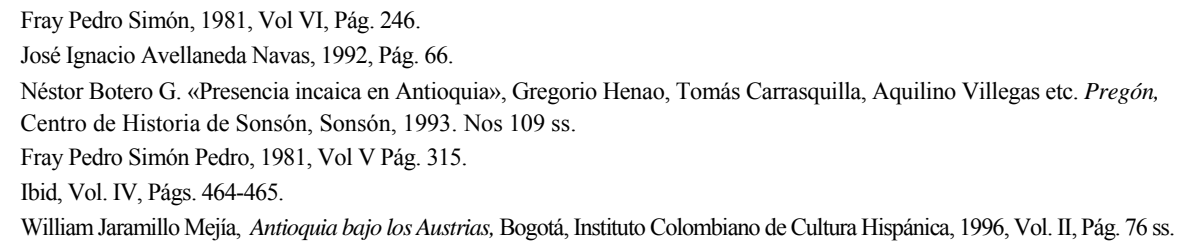


Zaragoza en 1581 y allí fue teniente general y justicia mayor. Después de 1588 se radicó en Antioquía, fue encomendero y alcalde y se contaba entre los primeros dueños de tierras en el Valle de Aburra. En 1568, cuando Gaspar de Rodas alistaba su empresa contra los Catíos contaba entre sus soldados con Alonso Serrano, mestizo, hijo de Florencio Serrano que, «aunque hijo de madre bárbara, él no lo era, ni de sus hechos; pues fueron siempre de muy valiente, suelto y diestro soldado»». ${ }^{25}$ También con él fue a la conquista de Zaragoza un mestizo «hijo de india y de español, llamado Pedro Martín Dávila (... y él muy amestizado por haber tomado mucho de la madre)». Le dieron indios en repartimiento y logró enriquecerse y fue a la conquista del Darién como capitán de su propia empresa. ${ }^{26}$ A esa empresa se vinculó también otro mestizo «soldado valeroso llamado Velasco, criollo de la ciudad de Pamplona, hijo del Gobernador Juan Velasco». ${ }^{27}$

La primera generación de mestizos, tal vez por el número limitado de casos y por su participación en la empresa conquistadora fue objeto de especial diferenciación y, aunque eran marcados en la designación como hijos de las indias, pudieron asimilarse a una condición relativamente favorable y similar a la de sus padres blancos. Según se registra en el Catálogo de Pasajeros a Indias, desde los primeros tiempos un buen número de esos primeros mestizos había viajado a España, seguramente con sus padres o a realizar gestiones relacionadas con sus ancestros «blancos»y, antes de 1570 , regresaban a las tierras americanas.

Con relación a quienes viajaban con destino al Nuevo Reino, en los primeros registros de 1567 se encuentran varios casos. El 23 de enero de 1567 se embarcaron para volver al Nuevo Reino de Granada Diego de Silva y Miguel Navarro, ambos mestizos y naturales de Tunja. El primero decía ser soltero e hijo de «Francisco de Silva y de una india». Navarro, también declaró ser soltero e «hijo de Pedro Navarro y de una india». ${ }^{28}$ Cinco días después, se registraron en Sevilla para regresar al Nuevo Reino Juan y Rodrigo de Sosa, hermanos «mestizos, naturales de Tunja, en el Nuevo Reino de Granada, solteros, hijos de Pedro de Sosa y de una india». ${ }^{29}$ En los días inmediatamente siguientes, se registró Diego de la Concha -29 de enero-, natural de Sevilla quien decía ir para Popayán, «llevando consigo a Rodrigo, mestizo». ${ }^{30}$ Juan Moro, -30 de enero- «mestizo, natural de Santa Fe en el Nuevo Reino de Granada, hijo de Alonso Moro y de una india»». ${ }^{31} \mathrm{Al}$ día siguiente, el 31 de enero, se registraron para

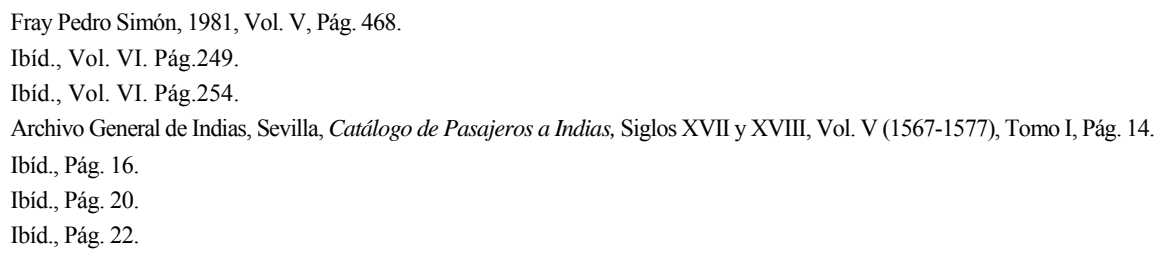


viajar a Indias: Alonso Hernández de Ledesma, «natural de Fuentes de Oñoro, jurisdicción de Ciudad Rodrigo y vecino de Vélez, en el Nuevo Reino de Granada, con su hijo Marcos, mestizo, al Nuevo Reino de Granada»; Gaspar de Ropero, «natural de Tunja en el Nuevo Reino de Granada, soltero, hijo de Martín Sánchez Ropero y de una india» y Sebastián Sánchez, «mestizo, natural de la ciudad de Popayán, hijo de Bartolomé Sánchez y de Francisca, india». ${ }^{32}$ Entre enero y febrero de aquel año de 1567, se hallan registrados en el Catálogo trece mestizos originarios del Nuevo Reino. A juzgar por la frecuencia de tales registros, era una cantidad apreciable de individuos de dicho origen que después de haberse desplazado a la península, ya se hallaba de regreso.

Otra situación que dio lugar al surgimiento de mestizos tiene su origen en las relaciones esclavistas. Desde el propio siglo XVI era frecuente la aparición de «mulatos», nacidos de la relación entre blancos y mujeres esclavas. Ya hemos mencionado el ejemplo de Alonso y Bartolomico, hijos de Juan Taborda. En la hueste que marchó contra Calarcá capitaneada por Diego de Ospina iban, por lo menos dos mulatos. Uno como piquero: Francisco de Mendoza, «mulato, mozo alentado que lo mostró bien ahora...». ${ }^{33} \mathrm{El}$ otro era de nombre Citare destacado en la lucha contra Chanama. ${ }^{34}$ En la empresa de Valdivia al norte de Antioquia, en 1574, iba como soldado «Mateo Fernandez Loro o Grifo, hijo de negro y de india, pero muy valiente, natural de la ciudad de Tunja». ${ }^{35}$ Posteriormente este mismo mulato acompañó a Rodas a la conquista de la misma zona en donde había encontrado la muerte Valdivia. ${ }^{36}$

Aunque, por diferencia con los mestizos, estos hijos heredaban, en los primeros tiempos la condición de esclavos, prontamente empezaron a figurar como «libres» $y$, en zonas donde la institución esclavista era importante, dieron lugar a la proliferación de «Mulatos y Zambos». En otro lugar hemos señalado cómo, desde 1630, empezó el proceso de manumisión de esclavos en Antioquia. Algunos de aquellos primeros casos se referían precisamente a mulatos. Tal es el ejemplo de la carta de libertad concedida, por Juana Pérez de Montilva, el 5 de junio de 1632, al mulato Juan, hijo de Juan Gil y la esclava Juana. En este caso, quien pagó a la Pérez los \$30 fue el padre Juan Gil que era «libre». ${ }^{37}$ Consecuentemente, a medida que aparecían más y más libres y formaban sus familias con otros libres, con indios, con mestizos o con zambos, crecía la capa de sus descendientes que, sin duda eran lo que podríamos llamar genéricamente «nuevos mestizos».

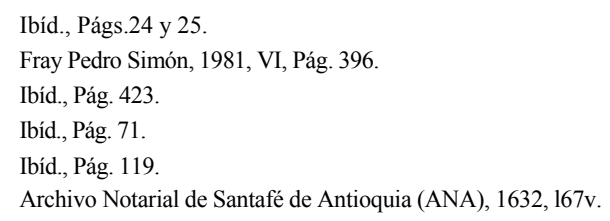




\section{MESTIZAJE, RECUPERACIÓN DEMOGRÁFICA Y NUEVO POBLAMIENTO. EL SIGLO XVII}

Promediando el siglo XVII la población mestiza en distintas regiones representaba ya una cantidad apreciable de la población. Aunque carecemos de estudios detallados sobre el asunto es evidente que aquel siglo significa simultáneamente recuperación demográfica y mestizaje. Tal vez la ausencia de censos pormenorizados como sí los tenemos para el siglo XVIII ha sido una limitación. No obstante, aunque implique trabajo más dispendioso es posible intentar alguna aproximación. Por ejemplo, en el caso de Antioquia, sabemos que a la formación de pueblos de indios que hizo Herrera Campuzano hacia 1616 sucedió un proceso de llegada significativa de mestizos a ocupar tierras asignadas a los indios.

Durante la visita realizada en 1670 por el gobernador Francisco de Montoya a los pueblos de indios de la provincia, el protector de naturales Don José Vásquez Romero informó que José Lozano, Nicolás de Montes, Juan Fernández, Francisco Osorio, los hijos de Diego Durango, Andrés, Juan y Rafael Holguín mulatos y Ventura de Taborda zambo, vivían dentro del poblado de Sabanalarga causando perjuicios a los indígenas y el mulato Francisco Goez, fue acusado de usurpar tierras de los indios con un cañaduzal. ${ }^{38}$ La presencia continuada de «libres» en las tierras del resguardo de Sopetrán llevó a que el fiscal de la Audiencia reiterara en 1687 la prohibición de que los mulatos y negros asistieran en pueblos de indios. Acontecimientos de la misma naturaleza se repiten durante el siglo XVIII, con frecuencia cada vez mayor. Al punto que, a mediados de aquel siglo se trató de extinguir este resguardo para garantizar una mayor cantidad, de tierras en manos de los «libres». Algo similar puede decirse del Valle de Aburra al cual llegaba desde comienzos del siglo XVII una creciente población mestiza. La Real Cédula que autorizaba, en 1675, la erección de la Villa de Nuestra Señora de la Candelaria de Medellín afirmaba entre sus consideraciones que: «Atendiendo a que en el dicho valle -de Aburra- había más de mil personas mulatos y mestizos que no tienen domicilio y andan vagamundos...». Por su parte, el censo levantado en esta misma ciudad con motivo de su erección, estaba compuesto por 280 familias de las cuales se especificaban 33 de mulatos y negros libres, 34 mestizas y 31 de indios.

De algunos de estos mestizos sabemos que se hallaban en el Valle de Aburra desde mucho antes de la erección de la villa. Algunos detalles de su familia ilustran su situación: Beatriz Arias (1), había casado con el conquistador Fernando Redondo y, desde mayo de 1614 había tenido una hija de nombre Catalina que posteriormente casó con Fabián Agudelo Salazar que era hijo ilegítimo; Juan Lezcano (3) se hallaba

38 Beatriz Patiño M., Riqueza, pobreza y diferenciación social en Antioquia, Medellín, inédito, 1985 
MESTIZOS Y MESTIZAJE

CUADRO No. 1 - MESTIZAJE EN ANTIOQUIA.

Pobladores de Medellín. Octubre 19 de 1675

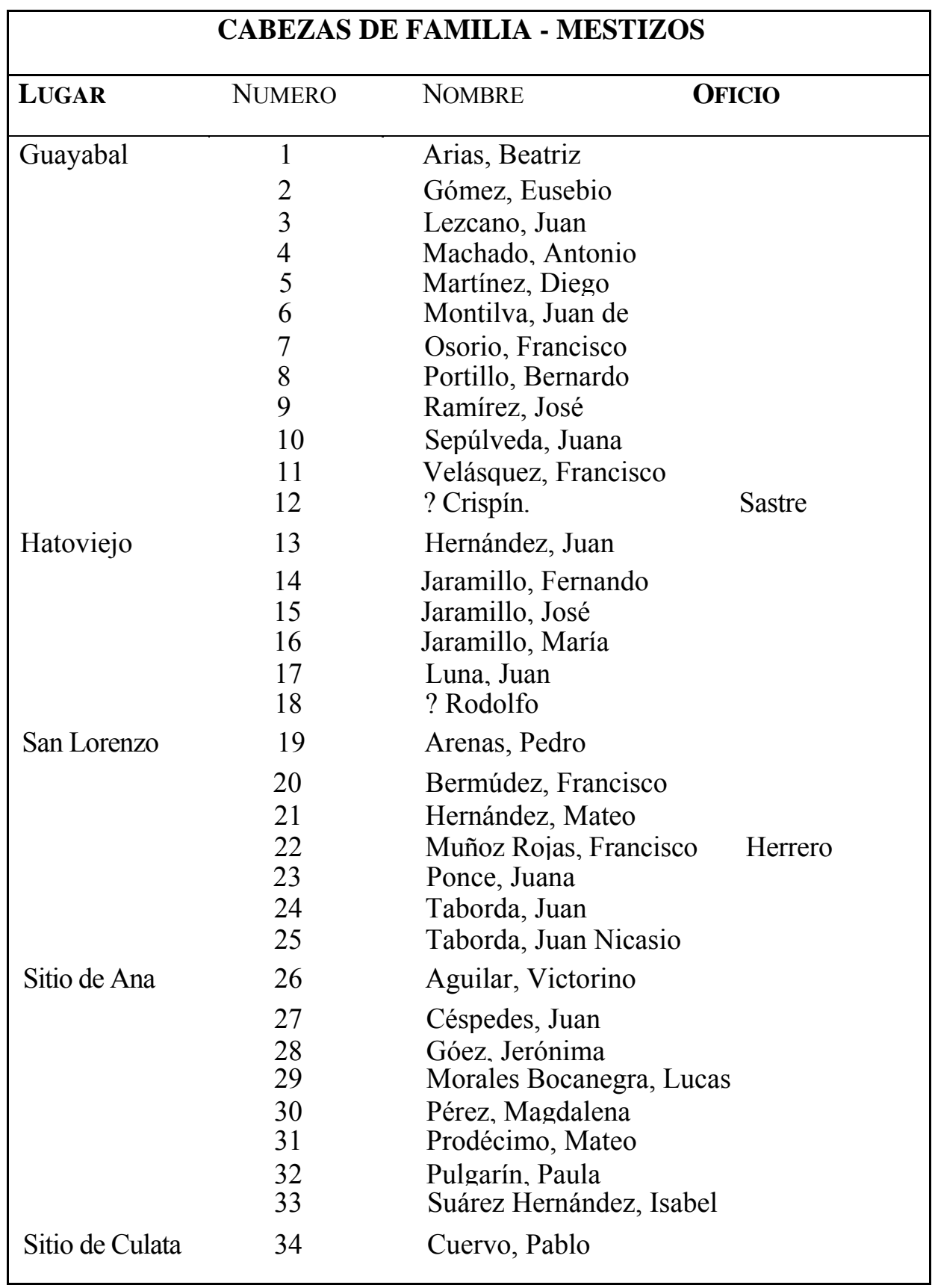

Fuente: Libro de Actas del M. I. Cabildo y regimiento de la Villa de Medellín, Medellín. Imprenta Oficial, 1937, Págs. 34 y ss. 
casado con Catalina Umieta Heredia y tenía 3 hijos; Antonio Machado (4) era hijo de otro mestizo llamado también Antonio Machado y casó con Juana Ramírez Coy, de cuya unión tenían 6 hijos; Francisco Osorio (7) casó el 8 de agosto de 1660 en Aburra con Francisca Martínez con quien tenía 3 hijos; Francisco Velásquez (11) era hijo ilegítimo de Alonso Velásquez de Obando y de la mestiza Magdalena Gómez. Nacido en 1632, desde 1665 adelantó pleito por sus derechos herenciales; Francisco Muñoz de Rojas (22) era herrero, casó el 8 de septiembre de 1669 con Juana Rondón y tenían 3 hijos; Victorino Aguilar (26) fue el segundo marido de Úrsula Pérez Romero con quien tuvieron un hijo de nombre Juan que después fue cura de Arma y tuvo con Juana Radillo un hijo ilegítimo de nombre Francisco; Juan Quiroga (27) era natural de Bogotá, llegó a Medellín a mediados del siglo XVII y el 18 de octubre de 1669 casó con otra mestiza: Paula Patino Pérez con quien tuvo cinco hijos; Lucas Morales de Bocanegra (29) era hijo de Ambrosio Morales y de la india Juana de la Estrella. El 4 de enero de 1656 casó con Juana María López Idárraga con quien tenía cinco hijos; Isabel Suárez Hernández (33), por su parte, era hija del mestizo Juan Suárez y la zamba Inés Hernández y casó con Gregorio de la Parra hijo ilegítimo de José de la Parra. Con un mulato de apellido Moya tuvo posteriormente una hija mulata llamada María de Moya. Se presume que la mayor parte de ellos se hallaba dedicada a las faenas agrícolas pero destaca la presencia de dos artesanos: el sastre Crispin y el herrero Muñoz de Rojas.

De estos mulatos conocemos algunos detalles que indican, de una parte, su temprana presencia en el Valle de Aburra y, de otra, la forma en que se iba tejiendo una intrincada red de lazos familiares. Francisco de Aguirre Ibarra (1) era hijo del español Francisco de Aguirre y de la mulata Catalina Ibarra. A su vez, esta Catalina había nacido de la relación entre otro español: Domino Ibarra y una liberta de Guayaquil de nombre Isabel González. Este Francisco de Aguirre casó con Margarita Elorza Lezcano y murió en 1697 dejando 6 hijos como descendencia. Cristóbal de Acevedo Redes (17) era hijo de un señor Acevedo y de la "negra horra" Inés Venero y había nacido en el Valle de Aburra en 1613. El 6 de octubre de 1640 casó con la india Ana Martínez con quien tuvo tres hijas zambas: Josefa, Juana María y Juliana. Su hija Josefa casó el 28 de diciembre de 1676 con su primo Dionisio Acevedo Duarte pero, desde 1663 había tenido con él a su hijo Benito. Dionisio era, a su vez, hijo de Antonio (nacido en 1609 y ya fallecido para el censo de 1675) y de Violanta Duarte (21). Luis de Acevedo Redes (18), hermano del anterior nació en 1615 en el Valle de Aburra y casó con Antonia Vargas con quien ya tenía cuatro hijos, uno de los cuales fue el Bachiller Jerónimo Facundo. Juan Antonio de Acevedo (20), posiblemente de la familia de los anteriores había casado el 4 de octubre de 1662 con Inés Josefa Agudelo y tenía 3 hijos. Los ejemplos anteriores de mestizos y mulatos para el siglo XVII en el Valle de Aburra dan cuenta de la forma como iba aumentando este tipo de población para convertirse, desde aquel momento en la mayoría de habitantes. Un 
siglo después, para 1787, se estimaba que en este mismo Valle había 707 blancos y 1554 "libres" lo cual significa que mestizos y mulatos ya representaban las dos terceras partes de la población.

CUADRO No. 2 - MESTIZAJE EN ANTIOQUIA.

Pobladores de Medellín. Octubre 19 de 1675

\begin{tabular}{|c|c|c|c|}
\hline \multicolumn{4}{|c|}{ CABEZAS DE FAMILIA - MULATOS Y NEGROS LIBRES } \\
\hline LUGAR & NUMERO & NOMBRE & OFICIO \\
\hline Guayabal & $\begin{array}{l}1 \\
2 \\
4 \\
5 \\
6 \\
7\end{array}$ & $\begin{array}{l}\text { Aguirre Ibarra, Francisco } \\
\text { Gil, Juan } \\
\text { Hernández, Juan } \\
\text { Martínez Coy, José } \\
\text { Romero, Luis } \\
\text { Torres, Juan de. } \\
\text { ? Ventura }\end{array}$ & «Negro Libre» \\
\hline Hatoviejo & $\begin{array}{l}8 \\
9\end{array}$ & $\begin{array}{l}\text { Herrero, Pedro Alejo } \\
\text { Leal, Antonio }\end{array}$ & \\
\hline Otrabanda & $\begin{array}{l}10 \\
11\end{array}$ & $\begin{array}{l}\text { ? Gabriel } \\
\text { ? Santiago }\end{array}$ & \\
\hline San Lorenzo & $\begin{array}{l}12 \\
13 \\
14 \\
15 \\
16\end{array}$ & $\begin{array}{l}\text { Bonifacio, Juan } \\
\text { Loaiza, Marcelo } \\
\text { Trejo, Ana } \\
\text { Trejo, Matías } \\
\text { ? Gregoria }\end{array}$ & \\
\hline Sitio de Ana & $\begin{array}{l}17 \\
18 \\
19 \\
20 \\
21 \\
11 \\
23 \\
24 \\
2 \mathrm{~S} \\
26 \\
27 \\
28 \\
29\end{array}$ & $\begin{array}{l}\text { Acevedo Redes, Cristóbal } \\
\text { Acevedo Redes, Luis } \\
\text { Acevedo, Elena } \\
\text { Acevedo, Juan Antonio } \\
\text { Duarte, Violanta de Acevedo } \\
\text { Gómez, Francisco } \\
\text { Hernández, Tomás } \\
\text { Latorre, Fabián } \\
\text { Ortega, María } \\
\text { Quiroga, Juan } \\
\text { Tabares, Francisco } \\
\text { ? Constantino } \\
\text { ? Rodrigo }\end{array}$ & Capitán \\
\hline Sitio de Culata & 30 & Pulgarín, Miguel & «Libre» \\
\hline
\end{tabular}




\begin{tabular}{|lcll|}
\hline LUGAR & NUMERO & NOMBRE & OFICIO \\
\hline Sitio del Totumo & 31 & ? Gregorio & «Libre» \\
Tasajera & 32 & Lezcano, Miguel & \\
& 33 & Molina, José & \\
& & & \\
& & & \\
\hline
\end{tabular}

Fuente: Libio de Actas del M. I. Cabildo y regimiento déla Villa de Medellín, Medellín, Imprenta Oficial, 1937. Págs. 54 y ss.

En otras regiones del país, el crecimiento se apoyaba aún en algunas circunstancias particulares de la vida social. Antes de finalizar el siglo XVI en Pamplona los mestizos y mulatos se ocupaban en tareas como la arriería, la mayordomía en haciendas y en labores artesanales. En abril de 1597 el mulato Francisco Vicente concertó con el capitán Pedro Orozco, vecino de Pamplona para servirle como arriero y cinco años más tarde era el mayordomo en la hacienda de su patrón en el Valle de Bochagá. De su parte, Juan Maraver "asentó para su servicio un pequeño "zambahigo" huérfano de una india de Batatas con el compromiso de tenerlo en su casa y servicio por toda su vida hasta que se hiciera hombre". ${ }^{39}$ También en Pamplona, aparecen entre 1577 y 1602, siete mestizos y dos mulatos como aprendices en oficios de zapatería, sastrería, herrería y platería. Para 1582 era oficial de sastrería el mestizo Alonso Duran y en 1590 figuraban como oficiales de zapatería el mulato Antonio y el mestizo Marcos Duran. Otro mulato, Hernán Pérez de Carmona era oficial de sastrería. Cinco años más tarde, en 1595 se registraron como herrero, espadero y sastre los mestizos Miguel, Juan Baez y Juan. ${ }^{40}$

En Santafé de Bogotá, la capital del Nuevo Reino, además de circunstancias similares a las enunciadas, aumentó notoriamente la población indígena femenina como resultado del uso de las indias en las tareas domésticas de carácter urbano y ello dio origen al crecimiento notorio de la población mestiza. Algo parecido a los procesos ejemplificados en Antioquia, Pamplona y Santafé, debió ocurrir en las otras zonas colombianas como lo indica la creciente aparición de sitios, lugares, vice-parroquias y parroquias y villas en lo que hoy conocemos como Santander y el Tolima. Estas modalidades utilizadas para designar el poblamiento dejan ver que la presencia de libres era cada vez más importante. ${ }^{41}$

39 Silvano Patón Villamizar, Historia del poblamiento y construcción del espacio hispánico en Pamplona, Cúcuta, Cámara de Comercio, 1996, Pág. 134.

40 Ibíd., Pág. 138 ss.

41 Armando Martínez Garnica, El régimen de la parroquia neogranadina en Santander, Bucaramanga, Universidad Industrial de Santander, 1994.

Ángela Inés Guzmán, Poblamiento e historias urbanas del Alto Magdalena Tolima, Siglos XVI, XVII y XVIII, Santafé de Bogotá, Fondo Mixto para la promoción de la cultura y las artes del Departamento del Tolima, Universidad del Tolima, abril de 1996. 


\section{LA SOCIEDAD MESTIZA. EL SIGLO XVIII}

Según el censo de la ciudad de Santafé de Bogotá, en 1778, la cantidad de mujeres indígenas -1.066- era prácticamente el doble de la de hombres que sólo llegaba a 574 individuos. ${ }^{42}$ Una vez en la ciudad, esta población femenina joven debió unirse abrumadoramente con los mestizos, libres y blancos que se "sonsacaban a las criadas indígenas para amancebarse o vivir maritalmente". ${ }^{43}$ Durante todo el siglo XVIII creció notoriamente la población mestiza al punto que los "libres de todos los colores" constituían la mayoría de la población como puede apreciarse en las cifras de los diversos grupos sociales para el año de 1778. Estudios parciales de los censos hechos hacia aquella fecha dejan ver la enorme importancia demográfica que tenía el grupo de libres.

CUADRO No. 3 - POBLACIÓN NEOGRANADINA A FINES DEL SIGLO XVIII Nuevo Reino, Santafé, La Sabana y Antioquia

\begin{tabular}{|lccccccccc|}
\hline & BLANCOS & $\%$ & INDIOS & $\%$ & NEGROS & $\%$ & LIBRES & $\%$ & $\begin{array}{r}\text { TOTAL } \\
\mathbf{1 0 0 \%}\end{array}$ \\
\hline NUEVO REINO & 474443 & 337 & 430910 & 30.6 & 83972 & 5.9 & 419685 & 29.8 & $\mathbf{1 4 0 9 0 1 0}$ \\
& & & & & & & & & \\
\hline SANTAFÉ & 7381 & 45.6 & 1640 & 10.1 & 684 & 4.2 & 6514 & 40.1 & $\mathbf{1 6 2 1 9}$ \\
& & & & & & & & & \\
\hline LA SABANA & 17396 & 22,0 & 29887 & 38.7 & 508 & 1.0 & 26193 & 38.3 & $\mathbf{7 3 9 8 4}$ \\
& & & & & & & & & \\
\hline ANTÍOQUIA & 8057 & 15.3 & 1520 & 2.8 & 7697 & 14.6 & 35552 & 67.2 & $\mathbf{5 2 8 2 6}$ \\
& & & & & & & & & \\
\hline
\end{tabular}

Fuente Relaciones e Infames de los Gobernantes de la Miera Ganada, Bogotá, Banco Popular, 1989, TI, cuadro A, Pág. 493.

Gracias a algunos estudios recientes sabemos de una situación similar en otras regiones colombianas. Veamos algunos ejemplos:

Mestizos, mulatos y "Libres" eran los 40.000 arrochelados de Cartagena que redujo a población Antonio de La Torre Miranda fundando o refundando, hacia 1774, los 43 pueblos en lo que hoy son los departamentos de Bolívar, Córdoba y Sucre. ${ }^{44}$ Igual condición tenían los 76.697 que el censo de 1779 contó en esa provincia. ${ }^{45} \mathrm{Al}$ mismo

\footnotetext{
42 Francisco Silvestre, Descripción del Reyno de Santafé de Bogotá, Biblioteca Popular de Cultura Colombiana, Bogotá, 1950. Julián Vargas L. La Sociedad de Santafé colonial, CINEP, Bogotá, 1990. Pág. 19.

44 Adolfo Meisel Roca, «Esclavitud, mestizaje y haciendas en la Provincia de Cartagena, 1533 -1851», Desarrollo y Sociedad, Bogotá. Centro de Estudios sobre Desarrollo Económico, CEDE, Uniandes, No. 4. Julio de 1980, Págs. 227-277.
} 
FRONTERAS • No. 1 / VOL. 1 / $1997 \bullet$

\section{CUADRO No. 4 - POBLACIÓN NEOGRANADINA A FINES DEL SIGLO XVIII}

TOLIMA

\begin{tabular}{|c|c|c|c|c|c|c|c|c|c|}
\hline & BLANCOS & $\%$ & INDIOS & $\%$ & NEGROS & $\%$ & LIBRES & $\%$ & $\begin{array}{l}\text { TOTAL } \\
\mathbf{1 0 0 \%}\end{array}$ \\
\hline S Antonio A & 564 & 15.4 & 14 & 0.4 & 153 & 4.2 & 2938 & 80.0 & 3669 \\
\hline Sta Rosa & 159 & 11.6 & 24 & 1.8 & 28 & 2.0 & 1158 & 84.6 & 1369 \\
\hline Alpujarra & 1602 & 42.4 & 157 & 4.2 & 12 & 0.3 & 2008 & 53.1 & 3779 \\
\hline Guamo & 377 & 18.6 & 150 & 74 & - & & 1496 & 74 & 2023 \\
\hline Bocaneme & 106 & 38.0 & 102 & 36.6 & 1 & 0.4 & 70 & 25.0 & 279 \\
\hline Ataco & 1649 & 50.5 & 10 & 0.3 & - & & 1606 & 49.2 & 3265 \\
\hline Guayabal & 307 & 29.6 & 19 & 1.8 & 19 & 1.8 & 691 & 66.7 & 1036 \\
\hline TOTALES & 4764 & 30.9 & 476 & 31 & 213 & 14 & 9967 & 646 & 15420 \\
\hline
\end{tabular}

Fuente: Ángela Inés Guzmán, Poblamiento e historias urbanas del Alto Magdalena Tolima. Siglos XVI, X'III y XIllI, Santafé de Bogotá, Fondo Mixto para la promoción de la cultura y las artes del Departamento del Tolima, Universidad del Tolima, abril de 1996.

\section{VALLE}

\begin{tabular}{|lccccccccc|}
\hline & BLANCOS & $\mathbf{\%}$ & INDIOS & $\%$ & NEGROS & $\mathbf{\%}$ & LIBRES & $\%$ & $\begin{array}{c}\text { TOTAL } \\
\mathbf{1 0 0 \%}\end{array}$ \\
\hline Buga (jurisd) & 3307 & 22.5 & 209 & 1.4 & 3457 & 23.5 & 7729 & 52.6 & $\mathbf{1 4 7 0 2}$ \\
& & & & & & & & & \\
\hline Buga (ciudad) & 1097 & 23.4 & 45 & 1.0 & 1171 & 25,0 & 2367 & 50.6 & $\mathbf{4 6 8 0}$ \\
& & & & & & & & & \\
\hline Tuluá & 7 & 0.1 & 1610 & 34.5 & 2989 & 64.0 & 65 & 1.4 & $\mathbf{4 6 7 1}$ \\
& & & & & & & & & \\
\hline Guacaí & 233 & 16.2 & 82 & 5.7 & 326 & 22.7 & 798 & 55.5 & $\mathbf{1 4 3 9}$ \\
& & & & & & & & & \\
\hline LLanogrande & 367 & 12.8 & 17 & 0.6 & 902 & $31-5$ & 1575 & 55.0 & $\mathbf{2 8 6 1}$ \\
& & & & & & & & & \\
\hline TOTALES & $\mathbf{5 0 1 1}$ & $\mathbf{1 7 7}$ & $\mathbf{1 9 6 3}$ & $\mathbf{6 , 9}$ & $\mathbf{8 8 4 5}$ & $\mathbf{3 1 2}$ & $\mathbf{1 2 5 3 4}$ & $\mathbf{4 4 2}$ & $\mathbf{2 8 3 5 3}$ \\
& & & & & & & & & \\
\hline
\end{tabular}

Fuente Eduardo Mejía Prado. Origen del campesino vallecaucano. Cali. Universidad del Valle, 1993, Censos de 1786. 
sector social pertenecían en 178044.163 habitantes de Tunja, 26.981 de Vélez, 17.735 del Socorro y 16.018 de Pamplona los que, con libres de otros lugares sumaban 119.434 mestizos neogranadinos. Agréguese a estas cifras los 29.034 que fueron contados en Santa Marta y se puede tener una dimensión aproximada del fenómeno de mestizaje a que venimos aludiendo. ${ }^{46}$ En el caso de Antioquia, los 35.552 llamados "libres de varios colores" se hallaban repartidos en dos grupos: 15.548 mestizos y 20.004 mulatos. En todos los lugares de la provincia de Antioquia los "libres de todos los colores constituían la mayoría de la población. Como lo ha señalado Luz Eugenia Pimienta para fines del siglo XVIII:

«...para el año de 1777 en la jurisdicción de Antioquia compuesta por Sopetón, San Jerónimo, Tonusco arriba, Hojas Anchas y el Valle de San Andrés la población total era de 4990 habitantes. De ellos 3490 eran «libres», lo cual significa la misma proporción, esto es dos tercios de los habitantes de esta zona."

Otras regiones tradicionalmente mencionadas como de predominio «blanca», Rionegro y Marinilla, tenían una población total de 9865 habitantes y de éstos, más de la mitad (5.372) correspondían a la categoría de «libres». Un último ejemplo, en Medellín los «libres» significaban el $63 \%$ de la población total. ${ }^{47}$ Como puede verse, las principales zonas de la provincia -Santafé de Antioquia, Medellín y el Oriente- se hallaban caracterizadas por un marcado predominio de los núcleos mestizos. Es lugar común entre los visitadores de la provincia subrayar la franca minoría del componente «blanco». ${ }^{48}$

\section{IA IMAGEN DEL MESTIZO ${ }^{49}$}

Una de las primeras imágenes de qué era y cómo se veía al mestizo por los españoles la debemos a Gonzalo Fernández de Oviedo quien, antes de 1550, en su Historia general y natural de las Indias afamaba: «...Que se deba creer lo que digo de los indios, pruébase porque la experiencia y obras de algunos lo mostraron y por los mestizos, hijos de cristianos y de indias, porque con grandísimo trabajo se crían y con mucho mayor no los pueden apartar de los vicios y malas costumbres $e$ inclinaciones». ${ }^{49}$

45 Hermes Tovar Pinzón, Camilo y Jorge Tovar M, Convocatoria al poder del número. Censos y estadísticas de la Nueva Granada 1750-1830, Bogotá, Archivo General de la Nación, 1994. Pág. 480.

46 Hermes Tovar Pinzón, Camilo y Jorge Tovar M. 1994, Págs. 380 y 514.

47 Luz Eugenia Pimienta Restrepo, Mestizaje y Sociedad en Antioquia, (1777-1810), Tesis de grado, Universidad de Antioquia, Departamento de Historia, Medellín, 1985. Pág. 37.

48 Ibíd., Pág.37.

49 Sobre este aspecto hay un buen trabajo de Beatriz Patino Millán, -Indios, negros y mestizos, La sociedad colonial y los conceptos sobre las castas». VIII Congreso Nacional de Historia de Colombia. Ciencia, cultura y mentalidades en la Historia de Colombia, Bucaramanga, LIS, 1992, Págs. 41-76.

50 Fernández de Oviedo y Valdés, Historiadores de Indias, Clásicos Jackson, Vol. XXVII, Buenos Aires, 1960, Pág. 28. 
Consecuente con esta imagen, desde el año de 1563 se establecieron algunas prohibiciones para los mestizos. Una de ellas se refería a su tendencia a vivir entre los indios. Por mandato del 2 de Mayo de 1563 se les prohibía vivir en los pueblos de indios y, como lo expresa el texto legal, la razón básica era su desarreglada conducta:

«...demás de tratarlos mal -a los indios- se sirven de ellos, enseñan sus malas costumbres y ociosidad y también algunos errores y vicios que podrán estragar y pervertir el fruto que deseamos en orden a su salvación, aumento y quietud y mandamos que sean castigados con graves penas y no consentidos en los pueblos... y en cuanto a los mestizos y zambahigos que son hijos de indias, nacidos entre ellos, y que han de heredar sus casas y haciendas, porque parece cosa dura separarlos de sus padres, se podrá dispensar» ${ }^{51}$

Por una cédula real de Felipe II fechada el 11 de Agosto de 1563 se autorizaba a los alcaldes indios para que: «...si los negros o mestizos hicieren algunos agravios o molestias, puedan prenderlos y detener en la cárcel hasta que el corregidor o alcalde mayor haga justicia»». ${ }^{52}$ Corría el año de 1582 cuando el Visitador Fray Jerónimo de Escobar, después de presentar la lista de vecinos de Almaguer, que había sido fundada hacía apenas treinta años, señalaba sus preocupaciones al respecto. Según su testimonio, una mujer mestiza, de nombre Mari Fernández era encomendero y el problema que más le preocupaba en esa localidad. La encomienda le había correspondido por ser viuda de su titular inicial, el portugués Luis de Mídelos. Según el visitador el caso

«...tiene necesidad de gran remedio porque ha sido causa de mucho daño para los indios, la casa de este vecino. La razón es porque está casado con una mestiza, mujer cruelísima y como en esta tierra, en toda ella no está quitado el servicio personal tiene indias en su casa e indios en quien hace justicias y castigos más que si fuesen esclavos... Demás de esto, este dicho Luis de Mídelos tiene dos hijos mestizos hijos de indias y suyos, hombres de a cuarenta años y un nieto de veinticinco, todos tres cruelísimos carniceros contra los miserables indios, y con ser de esta suerte y que es gente que vive mal estos mestizos y que hay proceso hecho contra ellos de que son hechiceros y que cuando tienen necesidades hacen juntar a los indios y con amenazas les sacan los dineros que tienen diciendo que si no los dan los azotarán y que si lo dan, que ellos tienen autoridad y mando para que se emborrachen y hagan sus bailes, y estos dichos mestizos se han mezclado entre ellos muchas veces y bailado, quitado el traje de españoles, con cami- 
setas de indios, y porque los indios traen cabello largo se ponían estos mestizos cabellera y bailaban entre ellos, a fin de sacarles el oro que tenían los miserables indios porque estos mestizos residen siempre entre los indios de su padre que son en un pueblo que llaman Pancitará, dos leguas de Almaguer... que es el más rico de este lugar...» ${ }^{53}$

Por otra parte, a los mestizos se adjudicaba en ocasiones, la realización de prácticas mágicas que para la época eran duramente perseguidas. En 1613 fue llevado al tribunal de inquisición de Cartagena el mestizo Luis Andrea, «hijo de español e india, natural del pueblo de Tubaxa (sic)». Según el relato correspondiente, este mestizo ejercía de mohán y:

«... habiéndole industriado el tío y tomádolo bien de memoria en el modo con que había de invocar al demonio, le dio la investidura del oficio, entregándole en unas ollas de barro ciertas piedrezuelas al modo y cantidad de habas y diciéndole el que había de guardar para invocarle. Apenas comenzó a menearlas en la olla dentro del templo, cuando se le apareció en figura humana... el demonio Buziraco... Porque Buziraco le era tan familiar como lo es un grande amigo de otro, sin faltarle ocasión de aparecérsele cuando le invocaba ${ }^{5}$

A lo largo del siglo XVII esta imagen negativa llevó a que se ratificara varias veces la prohibición a los mestizos de permanecer entre los indígenas pues se juzgaba que era completamente perjudicial. Así lo hicieron entre otros el Visitador Francisco de Herrera Campuzano quien, en 1614 expidió las ordenanzas para regular la vida en las minas de Guamocó cuyo numeral 9 establecía: «ítem, ordeno y mando que en la dicha población de los dichos indios ni entre ellos no vivan ni residan ningún español, mestizo, mulato, zambahigo, ni negro libre....> La misma prohibición estableció poco después, en 1627, Lesmes de Espinosa Saravia para Supía, Quiebralomo y Marmato. Como consecuencia de este tratamiento, desde fines del siglo XVI, la mayoría de los mestizos y mulatos y sus descendientes se encontraron sin posibilidades de acceder a la propiedad de la tierca por la vía de las mercedes reales y sin recursos para comprarla de manos de los propietarios blancos. Muchos de ellos entraron entonces al servicio de los blancos como criados, agregados, peones conciertos o jornaleros. Otros, se convirtieron en un nuevo factor de despojo para los indígenas pues, mediante diversos procedimientos usurpaban las tierras de resguardo y eran, por esta también, una nueva fuente de conflictos.

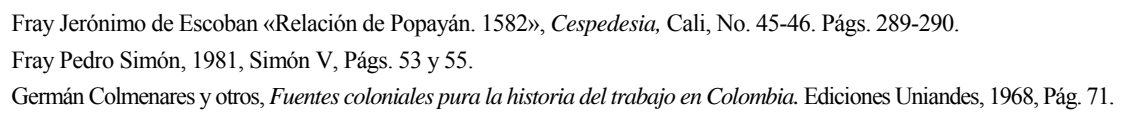


Desde 1623 en Pamplona se planteaba que tales mestizos eran un verdadero problema social pues según afirmaba el Gobernador Alonso Pérez Arroyo: «...Y es de forma que mucha gente de mal vivir, vagabundos y mestizos y mestizas andan todo el año de unos pueblos en otros haciendo muchas ofensas a Dios Nuestro Señor y llevando algunas indias solteras y otras casadas de unos pueblos en otros...». ${ }^{56}$ En la misma provincia de Pamplona, veinte años después el visitador Diego Carrasquilla Maldonado inició un proceso contra 18 mestizos y resolvió expulsarlos del Real de Minas de las Vetas. Las consideraciones del Visitador dejaban apreciar lo ocurrido:

«...en el (Real de Minas) asisten muchos hombres y mujeres mestizos y otros, gente ociosa y vagabunda y que sin tener oficio ni ocupación ninguna, ni labrar minas ni ser mineros asisten entre los indios y les han hecho daños y agravios... y que los dichos mestizos han inquietado a sus mujeres daños y agravios... diciéndoles cosas muy mal dichas y dignas de ejemplar castigo.... ${ }^{57}$

Como éstos, son frecuentes los casos en que las autoridades consideraban a la población mestiza como causante de desórdenes y dificultades sociales. A los llamados mestizos se agregaban poco a poco los zambos y mulatos de origen negro y las distintas mezclas de tercerones, cuarterones, etc. Durante el siglo XVIII esta imagen negativa se había fortalecido notablemente y había incorporado las nociones de revoltoso y borracho. Basilio Vicente Oviedo describía a Sogamoso en estos términos: «Tendrá Sogamoso 200 indios y más de 500 vecinos blancos, lo más y cuasi todos mestizos, inquietos y revoltosos; allí se ejecutan muchas muertes por las muchas bebidas...» ${ }^{58}$ Según este mismo sacerdote, en la jurisdicción de Vélez se vendía mucha chicha, macucos y aguardiente: «por tener muchos pueblos comarcanos de indios y mestizos y ser éstos tan propensos y dados a esas bebidas, consumen y malbaratan todo su trabajo y agencia»." 59

El denominador común que pesaba sobre el mestizo era el desprecio de los blancos. Los funcionarios del gobierno generalmente lo calificaban como «vagabundo, inestable y hacedor de agravios» En 1758 el fiscal Moreno y Escandón se refería al descenso de la población indígena y al crecimiento del mestizaje en términos que ilustran bien la imagen prevaleciente del mestizo:

Jaime Jaramillo Unte, Ensayos sobre ;listona social colombiana, Bogotá, Universidad Nacional, 1968, Pág. 174.

57 Jaime Jaramillo Uribe, 1968, Pág. 175-176

58 Basilio Vicente de Oviedo, Cualidades y riquezas del Nuevo Reino de Ganada. Col. Memoria Regional, Gobernación de Santander, Bucaramanga, 1990, Pág. 176.

59 Ibíd. Pág. 220. 
«Pues siendo la naturaleza del indio inclinada a la ociosidad y vicios que de ella misma dimanan, unida con la de los mestizos que son reputados por de costumbres depravadas y perversas, vienen a tal estado que son casi innumerables los excesos en que se derraman así indios como mestizos; y aunque estas dos clases diversas muestran algún género de aversión la una a la otra, sin embargo la diaria experiencia me enseña que los indios se casan con mestizas y los mestizos con indias y vese aquí por otro conducto por donde esta nación se ha ido agotando» ${ }^{60}$

A comienzos del siglo XIX y en los primeros tiempos de la época republicana el mestizaje empezó a ser visto con carácter reivindicador. Si de lo que se trataba era de romper con la metrópoli colonial y si era preciso contar con la mayoría de la población en el proceso de afirmación de las nuevas naciones americanas, el mestizo era «lo propio»y, el mestizaje, el elemento fundamental en la construcción de la nueva identidad latinoamericana. En el caso de la naciente República de Colombia, la exaltación del llanero que había contribuido notablemente en las guerras de independencia era, a su vez, la exaltación de lo que hasta ahora no era ni blanco, ni indio, ni negro. En el mismo contexto, intelectuales de México, Perú y Brasil empezaron a subrayar la prevalencia de una imagen positiva de las distintas mezclas que se concretaban en la presencia social de mestizos y mulatos. Con razón Sánchez Albornoz ha afirmado que: «Tanto en Hispanoamérica como en Brasil se abrazó la creencia de que la variedad de origen y el cruzamiento constituían una suerte de virtud. La mezcla no disminuía sino que agregaba calidad; enriquecía al género humano». ${ }^{61}$

A lo largo del siglo XIX eso significan las contribuciones del chileno Francisco Bilbao (1817-1888) quien pedía la «desespañolización y descatolización» de estas sociedades y que, durante su exilio en Francia consignó su agudo pensamiento en la obra titulada: «El evangelio americano». ${ }^{62}$ Eso es también lo que marca el pensamiento del mexicano Justo Sierra que hizo un sentido elogio del mestizaje y reconoció en él la «personalidad autónoma» que debía identificar la construcción de las nuevas nacionalidades. Entre todos ellos se destaca José Vasconcelos quien, a comienzos de este siglo afirmó tajantemente: «nuestra América es patria y obra de mestizos, de dos o tres razas por la sangre y de todas las culturas por el espíritu». Según sus ideas, lo mestizo y el mestizaje es la base de la nacionalidad. Su propuesta conceptual que califica al mestizo latinoamericano como la «RAZA CÓSMICA» poseedora de todas las virtudes y capacidades es, tal vez, el punto culminante de esta mirada positiva.

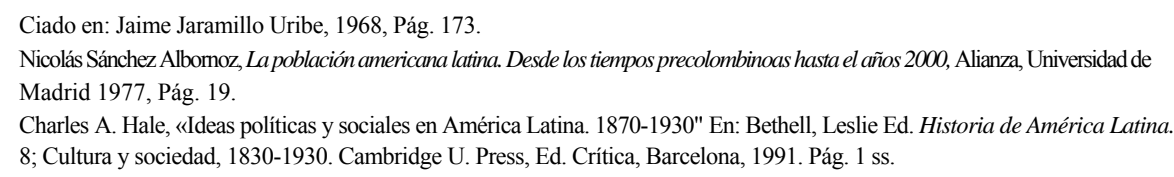


«Esta concepción sincrética del destino de América Latina fue ampliamente compartida, salvo las inevitables excepciones. La noción de mestizaje se convirtió en una formidable fuerza integradora hacia el interior a la par que elemento diferenciador con respecto al resto del mundo. Al rechazarse el predominio de cualquier tronco originario y afirmarse las características mestizas de la cultura y del pueblo latinoamericanos, el juego recíproco de los grupos étnicos pasó a ser factor central del proceso histórico y cuestión de interés general.» ${ }^{63}$

Por contrapartida, en los primeros decenios del presente siglo el surgimiento del «indigenismo» y, de otro lado, la prevalencia del pensamiento racista que identificó la noción de «progreso» con el legado blanco europeo opacaron las tendencias a la reivindicación del mestizo hasta nuestro tiempo. Parece pues llegada la hora de volver a reconocer su papel en la historia de estas sociedades y ello significa recuperar una historia varios siglos silenciada. Más que apologías, elogios o diatribas, es preciso indagar cómo ha sido la historia del mestizaje y del mestizo para tener una adecuada valoración de su significado en la historia de los pueblos latinoamericanos.

\section{EL ASUNTO DE LA «ILEGITIMIDAD»}

El producto de las relaciones sexuales de los blancos con indias y negras, no incorporaba casi nunca el matrimonio. Por lo mismo, los hijos nacidos de tales relaciones aparecían contrariando los cánones éticos que el cristianismo había traído consigo. Casi necesariamente decir mestizo o mulato equivalía a decir hijo ilegítimo con toda la carga de discriminación que ello representaba en nuestras sociedades hasta muy recientemente. Ya hemos aludido a los hijos de españoles e indias que fueron desde el primer momento un alto número. También fueron muchos los hijos de blancos en sus propias esclavas y ello resultó ser especialmente significativo en las provincias en donde se formaron sociedades de carácter esclavista como Cartagena, Popayán y Antioquia. Que era una práctica generalizada lo deja ver el caso de Ignacio de Mosquera y Figueroa, Teniente de Gobernador de Nóvita en el año de 1801. Mosquera fue acusado por maltratar a sus esclavos pero, principalmente, por tolerar los malos tratos que su manceba, la mulata María Losada, daba a los esclavos del propio Mosquera. Todos los testigos declararon que Mosquera tenía relaciones amorosas con la mulata y que de ellas habían resultado varios hijos. En el juicio Mosquera acusó a los testigos del mismo cargo de vivir amancebados con las negras esclavas y en ello incluía al propio cura de Nóvita. ${ }^{64}$ En Antioquia la práctica de usar las esclavas para la

63 Nicolás Sánchez Albornoz, 1977, Pág. 19-

64 Jaime Jaramillo Uribe, 1968, Pág. 52. 
satisfacción de la sexualidad era tan común que se atribuye a Don Mateo de Castrillón, rico propietario del Valle de Aburra a comienzos del siglo XVII, el cumplimiento frecuente del «precepto colonial» descrito por Moretón:

«Es muy usual que un caballero después de comer mande al campo por una de sus favoritas, que a toda prisa se le remite a casa llevándosela a su cuarto bien calientita y anegada en sudor, en cuyo estado la goza y después se toma la siesta de una hora o así mientras ella vuelve a la labor hasta la noche; de este modo se apropia una por turno, casi a diario, rondando con tanta libertad y dignidad como un plenipotenciario entre arrobos de delicias»». ${ }^{65}$

Por manera que, además de los once hijos de su matrimonio con María Vásquez Guadramiros, debieron ser muchos más los «dignos representantes de la estirpe» de los Castrillón que le sucedieron, aunque ello debió ocurrir en condición de ilegítimos como era el $30 \%$ de los niños bautizados en la iglesia de Medellín en los cinco años que antecedieron a su fundación. (1670-1675). Aunque la mayor parte de ellos se registraba como «hijo», mientras que los restantes eran «hijo legítimo», buena parte de los ilegítimos eran expósitos. En los libros bautismales estos expósitos se llamaban eufemísticamente «hijo de la pila» o «hijo de la iglesia». ${ }^{66}$ Precisamente en el año mismo de fundación de la «Villa» (1675) el porcentaje de ilegitimidad aumentó parcialmente y llegó hasta el 40\% pues sobre 45 niños bautizados, 18 de ellos respondían a la condición de ilegítimos. Entre éstos, el 27 de enero, fue bautizado como «hijo de la iglesia» Dionisio, «de edad al parecer de un mes». La misma condición tenían, pocos días después, el 11 de febrero, Manuel, «de dos meses» y dos días más tarde, Juan José, «de ocho meses».

Esta no era una situación exclusiva de Antioquia. En un estudio sobre la provincia de Tunja correspondiente al período 1659-1700, los bautizos y el grado de ilegitimidad dejaban ver distintas conductas al respecto en los diversos grupos. Según el registro los bautismos se repartían así:

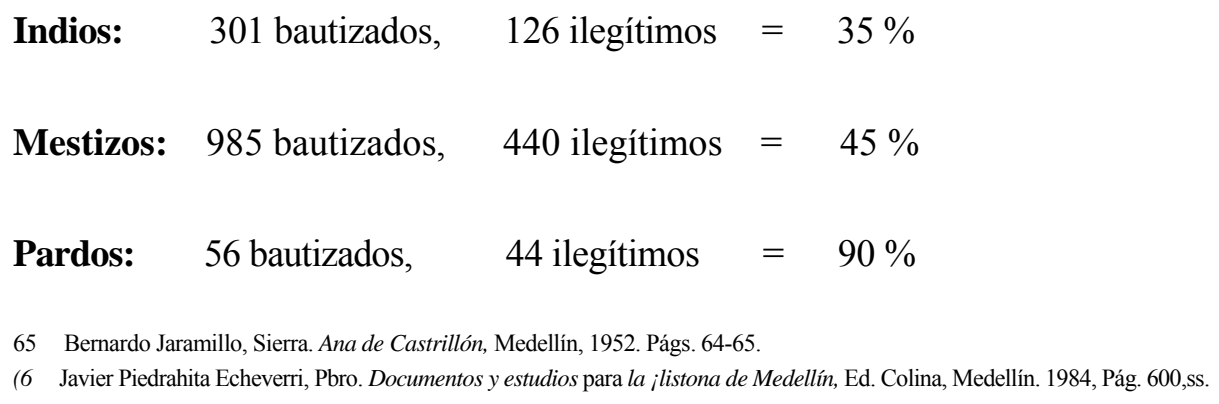


Por otra parte, en el censo de Santafé de 1793, el $90.4 \%$ de los indios y el $76.2 \%$ de los mestizos se declaraban «solteros». Esta resistencia a las formas institucionales no indica que carecieran de pareja. El gran número de mujeres indígenas y mestizas que iniciaban tempranamente su vida sexual y el aparente predomino de «solteros» indica «la existencia de un concubinato bastante generalizado y de una gran cantidad de relaciones por fuera de la unión estable-. ${ }^{67}$ Esta situación hizo posible el mayor crecimiento de la capa de mestizos pero incluyó en ella la carga de «Ilegitimidad» que la caracterizaba.

Precisamente en el momento en que la nomenclatura que servía para clasificar tomaba un aire erudito y se iba enredando se hacía más difícil precisar la filiación de los individuos pues «la ilegitimidad borraba las pistas en la generación precedente y la fisonomía apenas proporcionaba aproximaciones groseras». La documentación correspondiente a aquella época indica sin duda la frecuencia de los nacimientos extramatrimoniales en la sociedad latinoamericana. Según Sánchez Albornoz los estudios recientes basados en los libros de bautismo, van perfilando las dimensiones de la cuestión.

«Entre 1741 y 1845 el promedio de alumbramientos ilegítimos en la parroquia de la catedral de Sao Paulo fue de $23 \%$ y el de los niños expósito de nada menos que del $16 \%$. De cada cien criaturas, treinta y nueve eran, por consiguiente, legalmente bastardos. Tres parroquias de la colonia francesa de SaintDomingue y la de Quillota, situada en el norte Chico chileno ilustran por su lado situaciones semejantes en el siglo siguiente. En Quillota, por ejemplo, una cuarta parte de los conducidos a la pila bautismal entre 1690 y 1729 arrastraban esa tacha. La proporción ascendió luego hasta un tope de 37,9 \% en 1740-49. A su vez, la parroquia, también rural de Santa María en la provincia argentina de Catamarca arroja cierta luz sobre el siglo XIX... de cada cuatro bautizados allí en el quinquenio 1813-18 uno era nacido al margen de las nupcias; un cuarto de siglo más tarde, 1834-44 arañaban la mitad". ${ }^{68}$

En las respectivas parroquias del Sagrario de las ciudades de Guadalajara y México, alrededor de una quinta parte de las aguas bautismales fueron impuestas, en 1821, a hijos de padres desconocidos o a niños calificados de manera beatona de «huérfanos» (González Navarro, 1970)». ${ }^{69}$

\section{LA DISCRIMINACIÓN}

Como se ha señalado, el mestizo es también un producto de la conquista europea. No obstante, por la situación que le rodea, desde sus orígenes es objeto de

67 Julián Vargas L, 1990, Pág. 16.

68 Nicolás Sánchez Albornoz, 1977, Pág. 144.

69 Ibíd., Pág. 143. 
discriminación. En la primera época los mestizos se asimilaban fácilmente a la condición de conquistador o colonizador que tenía su padre y pasaban por blancos, si los reconocía el padre o por indios en virtud de los mecanismos de filiación de aquella época. Además, los primeros mestizos se beneficiaron de los sentimientos que el parentesco directo alentaba, pero también, en tanto que estrato, servían de intermediarios o auxiliares para la tarea imperiosa de descomposición de la sociedad aborigen. ${ }^{70}$ Ellos mismos, por su condición no eran tributarios y más bien, su papel en aquella sociedad los ponía de lado de sus padres blancos y en abierta descalificación de su origen indígena. Tal parecería que se comportaban como blancos, y se asumían a sí mismos como tales. Prontamente su número creció y con él, su papel activo en muchos de los frentes de la vida social lo que hizo imperativo diferenciarlos de los demás grupos étnicos. Los «blancos» que veían amenazado su poder apelaron muy temprano a reforzar sus privilegios generando mecanismos de discriminación que no sólo negaban al mestizo posibilidades, sino que permitían que se construyera una ideología que jerarquizaba según el color de la piel.

Aunque originado en el cruce del blanco con el indio, de los indios que se fugaban para eludir el tributo, de los esclavos que hacían lo propio para conseguir la «libertad» o de los negros que, por diversas razones obtenían carta de manumisión, desde los primeros tiempos, al mestizo le estaba vedado acceder a las encomiendas y poco a poco se le fueron negando otras relaciones con los indios. Se les prohibía vivir en los pueblos de indios, negociar con ellos o utilizarlos como sirvientes o cargueros. Curiosamente, en estos, como en otros casos, la legislación se ocupaba de ellos solamente para establecer prohibiciones que limitaban su vida y su conducta.

No era fácil para el mestizo recibir mercedes de tierras y siempre los funcionarios alegaron lo complicado de los trámites para explicar esta dificultad. Para conseguir tierra, muchos mestizos debieron ocupar y despojar progresivamente a los indios de aquellas que estaban en los resguardos, como sigue ocurriendo hasta hoy. Para ellos no había escuelas y su posibilidad de oficio se hallaba circunscrita a las actividades serviles. Tampoco era permitido al mestizo ocupar cargos públicos pues la burocracia, aún en sus rangos más bajos era reputada como actividad «noble» que debía estar vedada a los plebeyos. ${ }^{71}$ En el caso de Antioquia, la discriminación operaba también sobre el espacio. El cabildo de la recién erigida Villa de La Candelaria de Medellín decretó el 3 de enero de 1676 que: «... los indios, mulatos y mestizos que vivan inmediatamente a la plaza principal, se retiren a los arrabales donde se les de solares 
y los que tuvieren ocupados en lo inmediato a la plaza principal se repartirá a las personas españolas y de más lustre...». ${ }^{72}$

La discriminación social pesaba gravemente sobre este núcleo creciente de población. Tal vez, lo que mejor definía al mestizo era el NO: No eran españoles, ni indios, ni negros; NO eran conquistadores, ni encomenderos, ni tributarios, ni esclavos; NO eran propietarios, ni vecinos, ni podían ocupar cargos públicos; NO podían vivir entre los indios ni disponer de su vivienda en el «marco de la plaza»; NO encarnaban la cultura europea pero tampoco las tradiciones culturales de indios y negros. NO podían comportarse como los blancos pero debían renegar de las formas propias de indios y negros. NO era objeto directo de las «doctrinas de indios», no había para él escuelas ni espacios sociales o institucionales que les fueran propios. NO era portador de una TRADICIÓN pero debía afirmar su superioridad y diferencia frente a indios y negros. A medida que su número iba en aumento iban apareciendo nuevas formas de discriminación. Una de ellas tenía que ver con la necesidad de diferenciarlos por una designación que diera cuenta de su grado de mestizaje: Primero fueron Mestizo, Mulato y Zambo. No obstante, los múltiples y diversos cruces con otros «mezclados» dieron lugar a una verdadera multiplicación de designaciones.

Con razón, el historiador Sánchez Albornoz ha escrito que:

«A esta típica reacción señorial se sumó la propensión clasificatoria propia de la mentalidad ordenancista y racionalizadora de aquel siglo que produjo, bajo otros cielos un Linneo. Al igual que con las especies vegetales y animales, cabía someter a los hombres a clasificación. Entonces se difundiría en la América española la complejísima nomenclatura de las castas de mezcla, que los artistas poblanos Ignacio de Castro y José Joaquín Magón ilustraron con su pincel en cuadros famosos reproducidos con frecuencia. Cada mezcla posible a partir de los tipos puros recibió una designación. Los nombres de mestizo, mulato o zambo eran antiguos y no necesitan mayor aclaración. Los de tercerón, cuarterón y quinterón son, por otra parte suficientemente expresivos por sí mismos. El habla peruana de nuestros días ha preservado en fin, el uso de cholo y chino. ¿Pero quién recuerda hoy el significado de nombres como castizo, morisco, lobo, jibaro, albazarado, cambujo, barcino, puchuel, cayote, cahmizo, gálfarro, genízaro, grifo, jarocho y zambahigo, o los más pintorescos de salta-atrás, tente en el aire, no te entiendo, ahí estés, etc.? Complejidad adicional, las designaciones cambiaban de acuerdo con las regiones: chino era mas coloquial en Perú y en Nueva España, en tanto que Venezuela prefería zambo.

72 Libio de Actas del Muy Ilustre Cabildo de k Villa de Nuestra Señora de la Candelaria de Medellín, Acotaciones de Manuel Monsalve, Medellín, 1937, Vol. I, Pág. 95. 
En Brasil curiboca, cabodo y mameluco designaban de Norte a Sur la misma descendencia del portugués y de la india... / En el habla popular se preferían expresiones eufemísticas mas vagas, como las de moreno y pardo por negros y mulatos. Pardas eran a veces incluso los propios negros y otras los mestizos. ${ }^{173}$

Finalmente, frente a la complejidad que la situación presentaba se acuñó la expresión usada en algunos censos del siglo XVIII: «Libres de todos los colores» $\mathrm{o}$, simplemente «Libres». Donde se prestó mayor atención a tales diferencias fue en las grandes ciudades, como lo atestigua la célebre descripción de Antonio de Ulloa de las castas del puerto de Cartagena. En los centros urbanos la confusión podía hacer peligrar la estratificación antes que en el campo, donde el dominio marcado del señor feudatario era indiscutido. ${ }^{74}$ Para el siglo XVIII los conceptos mestizo, mulato o zambo eran considerados como ofensa cuando se referían a quienes no tenían tal origen. Muchos fueron los pleitos adelantados en los tribunales por el uso de estas expresiones que se consideraban injuriosas y que difamaban de las personas si eran o se estimaban como «blancas-. Como sirviente, peón o agregado su condición social lo hacía claramente dependiente de los blancos. Prontamente, para ser «libre y gozar de cierta independencia el mestizo encontró una posibilidad económica en las tareas artesanales, en el pequeño comercio, en la colonización de nuevas tierras, en el mazamorreo del oro y en las tareas de carga y transporte. Culturalmente es el mestizo quien más prontamente reniega de cualquier tradición que lo vincule a su origen indígena o negro y quien entra rápidamente en un proceso de «blanqueamiento», adoptando costumbres y pautas de comportamiento que le permitan parecer blanco aunque con plena conciencia de la discriminación que sobre él se ejerce. Ocultar el origen indígena o negro fortalece así su posibilidad de sortear los efectos de la discriminación pero lo obliga a ir construyendo elementos propios que, evidentemente, no son europeos. Al parecer, su única posibilidad cultural pasaba por «blanquearse» y esto significa una especie de condición esquizofrénica desde el punto de vista de sus valores, ideas y símbolos: tratar de ser y parecer como «blanco» pero NO ser blanco.

\section{LO URBANO Y LO RURAL}

El fenómeno del mestizaje es principalmente urbano durante la colonia. La velocidad de mestización es mayor en los centros urbanos que en las zonas rurales. Los pueblos son el lugar obligado de encuentros interétnicos y de reuniones colectivas periódicas como el mercado, las festividades, las chicherías, tiendas y cantinas o de encuentros permanentes como lo determinan las tareas artesanales masculinas y el servicio doméstico de las mujeres. El estudio de Julián Vargas sobre Santafé de Bogotá permite

73 Nicolás Sánchez Albornoz. "La Población de América Latina: desde los tiempos precolombinas al año 2000". Alianza Universidad, Madrid, 1977, Pág. 143.

74 Jaime Jaramillo Uribe, 1968, Págs. 143-144

75 Julián Vargas L, 1990, Pág. 19. 
apreciar que los 33.000 mestizos que se contaron en 1778 se hallaban repartidos entre el campo y la ciudad. Aunque la mayoría se hallaban en el campo, su proporción representaba más del $40 \%$ de la población urbana y era menor en las zonas rurales. ${ }^{15}$

Por contraste, en Antioquia, la existencia de características propias de su modelo social, abrió la puerta a una progresiva consolidación del mestizo como «libre», como trabajador independiente y como propietario rural. Ello dio lugar al modelo de sociedad de pequeños y medianos propietarios y de independencia económica que caracterizó durante mucho tiempo a la provincia. El mazamorrero, el colono, el arriero, el pequeño comerciante y el artesano son quizás los tipos sociales que caracterizan en mejor forma esta situación. Sobre sus hombros se construyó buena parte de la historia regional en los años finales de la colonia y durante la etapa republicana. Esa es nuestra herencia dominante y gústenos o no, a ella no podemos renunciar, a pesar de los esfuerzos de muchos por disfrazarnos de blanco, indio o negro. Vale la pena que iniciemos también, con motivo de este nuevo Centro de Estudios una campaña intelectual por el AUTODESCUBRIMIENTO DEL MESTIZO. Sólo la conciencia como mestizos americanos y como herederos de ese legado colonial ha de servirnos para reconocer nuestras propias limitaciones y ventajas y para afrontar con mayor claridad los retos que nos presenta la historia de hoy.

Medellín, abril de 1997 